\title{
Pathobiology of cancer chemotherapy-induced peripheral neuropathy (CIPN)
}

\author{
Yaqin Han ${ }^{1,2}$ and Maree T. Smith ${ }^{1,2 *}$ \\ Centre for Integrated Preclinical Drug Development, The University of Queensland, Brisbane, QLD, Australia \\ ${ }^{2}$ School of Pharmacy, The University of Queensland, Brisbane, QLD, Australia
}

\section{Edited by:}

Susan Hua, The University of

Newcastle, Australia

Reviewed by:

Joel S. Greenberger, University of

Pittsburgh Medical

Center-Shadyside, USA

Andreas Bergdahl, Concordia

University, Canada

*Correspondence

Maree T. Smith, Centre for

Integrated Preclinical Drug

Development, The University of

Queensland, Level 3, Steele

Building, St. Lucia Campus,

Brisbane, QLD 4072, Australia

e-mail:maree.smith@uq.edu.au
Chemotherapy induced peripheral neuropathy (CIPN) is a type of neuropathic pain that is a major dose-limiting side-effect of potentially curative cancer chemotherapy treatment regimens that develops in a "stocking and glove" distribution. When pain is severe, a change to less effective chemotherapy agents may be required, or patients may choose to discontinue treatment. Medications used to alleviate CIPN often lack efficacy and/or have unacceptable side-effects. Hence the unmet medical need for novel analgesics for relief of this painful condition has driven establishment of rodent models of CIPN. New insights on the pathobiology of CIPN gained using these models are discussed in this review. These include mitochondrial dysfunction and oxidative stress that are implicated as key mechanisms in the development of CIPN. Associated structural changes in peripheral nerves include neuronopathy, axonopathy and/or myelinopathy, especially intra-epidermal nerve fiber (IENF) degeneration. In patients with CIPN, loss of heat sensitivity is a hallmark symptom due to preferential damage to myelinated primary afferent sensory nerve fibers in the presence or absence of demyelination. The pathobiology of CIPN is complex as cancer chemotherapy treatment regimens frequently involve drug combinations. Adding to this complexity, there are also subtle differences in the pathobiological consequences of commonly used cancer chemotherapy drugs, viz platinum compounds, taxanes, vincristine, bortezomib, thalidomide and ixabepilone, on peripheral nerves.

Keywords: chemotherapy-induced peripheral neuropathy (CIPN), mitochondrial dysfunction, oxidative stress, intraepidermal nerve fiber (IENF) degeneration, loss of heat sensitivity

\section{INTRODUCTION}

Chemotherapy-induced peripheral neuropathy (CIPN) is a common and potentially dose-limiting side effect of many cancer chemotherapy drug treatment regimens (Burton et al., 2007). The prevalence of CIPN varies from 10 to $100 \%$ depending upon the particular anticancer drug or drug combination administered, the dosing regimen, the methods of pain assessment and the particular patient situation (Balayssac et al., 2011). The development of CIPN may result in dose reduction of the cancer chemotherapy agents or a switch to less efficacious agents or even cessation of treatment in the extreme (Gutiérrez-Gutiérrez et al., 2010).

Typically, CIPN presents in patients with a "stocking and glove" distribution in the feet and hands, respectively, due to the vulnerability of the long nerves (Boland et al., 2010). Sensory symptoms that are commonly reported include paresthesia, dysesthesia, allodynia, hyperalgesia, hypoalgesia or pain that is burning, shooting or electric-shock-like (Boland et al., 2010). Painful symptoms may persist well beyond discontinuation of treatment (so called "coasting") (Quasthoff and Hartung, 2002) resulting in a condition as painful or more painful than the original cancer. Furthermore, although slow recovery of peripheral nerve damage may occur in patients with CIPN, this is not always the case and so pain may persist (Peltier and Russell, 2002).

Anticancer drugs that most commonly induce CIPN are platinum compounds (cisplatin and oxaliplatin), spindle poisons/antitubulins including vincristine and paclitaxel (Wolf et al., 2008; Balayssac et al., 2011), and some newer agents such as the proteasome inhibitor, bortezomib (Hoy, 2013), ixabepilone (Goel et al., 2008) and thalidomide (Kocer et al., 2009). A wide range of solid and hematological malignancies are treated with these compounds and polychemotherapy schedules are used to enhance treatment effectiveness (Cavaletti and Marmiroli, 2010). However, the latter also increase the risk of CIPN (Burton et al., 2007; Argyriou et al., 2013).

The prevalence of cancer is increasing globally with an estimated 17 million new cases projected by 2020 (Kanavos, 2006; Paice, 2011). Cancer survival rates have increased dramatically as new treatments and older therapies are refined to have a greater antitumor effect. This means that the landscape of "cancer pain" has shifted into a form of long term chronic pain in many instances (Burton et al., 2007). In clinical practice, CIPN is poorly diagnosed and under-treated to the detriment of patient quality-of-life and there is no proven method for prevention of CIPN (Balayssac et al., 2011). Although drugs used to provide symptomatic relief of CIPN often lack efficacy and/or have unacceptable side-effects (Balayssac et al., 2005), a recent 5 -week randomized, placebo-controlled clinical trial found that oral duloxetine at $60 \mathrm{mg}$ daily produced significant relief of CIPN above placebo (Smith et al., 2013). Despite these promising findings, there is nevertheless a large unmet medical need for novel, 
well-tolerated analgesic agents to improve relief of CIPN. In the past decade, new insights on the mechanisms underpinning the pathogenesis of CIPN (Balayssac et al., 2011) have been made possible by the advent of rodent models enabling new targets to be identified for use in pain therapeutics discovery programs. Such studies are discussed in the following sections of this review.

\section{STRUCTURAL CHANGES IN PERIPHERAL NERVES}

Cancer chemotherapy agents may differentially affect specific peripheral nervous system (PNS) structures to produce neuronopathy, axonopathy and/or myelinopathy that contribute to the pathogenesis of painful CIPN (Ocean and Vahdat, 2004; Balayssac et al., 2011) (Table 1 and Figure 1).

Cancer chemotherapy-induced peripheral nerve injury appears to be due primarily to axonopathy (McDonald et al., 2005; Persohn et al., 2005; Gilardini et al., 2012) that is seen both in patients with CIPN (Cata et al., 2007; Burakgazi et al., 2011) and in rodent models of CIPN (Cavaletti et al., 2007; Boyette-Davis et al., 2011). Thus, peripheral nerve degeneration or small fiber neuropathy is generally accepted as underpinning the development of CIPN (Liu et al., 2010; Boyette-Davis et al., 2011; Burakgazi et al., 2011; Wang et al., 2012).

\section{THE LONGEST AXONS ARE THE FIRST AFFECTED}

Peripheral nerves contain a variety of nerve fibers that differ in their respective morphology, degree of myelination, function and biochemical features (Gutiérrez-Gutiérrez et al., 2010). These various fiber types are differentially sensitive to the neurotoxic effects of cancer chemotherapy agents with the longest nerves having the greatest vulnerability (Wilkes, 2007; Gutiérrez-Gutiérrez et al., 2010). This may be related to their higher metabolic requirements (Chen and Chan, 2006; Mironov, 2007). Clinically, symptoms develop initially in the feet and hands, followed by proximal progression to the ankles and wrists in a "stocking and glove" distribution (Lomonaco et al., 1992; Wolf et al., 2008).

\section{MYLELINATED FIBERS ARE DAMAGED WITH/WITHOUT ALTERED MYELIN STRUCTURE WHEREAS UNMYELINATED FIBERS ARE MOSTLY UNAFFECTED}

Myelin is a lipid- and protein-rich sheath that insulates axons and facilitates faster conduction of nerve impulses compared with unmyelinated axons (Gilardini et al., 2012). Although myelinated fibers are damaged (Cata et al., 2006), perhaps even by preferential selection (Cavaletti et al., 1995; Dougherty et al., 2004), the extent to which demyelination is a key pathobiological event in CIPN is unclear. For example, using X-ray diffraction capable of detecting even subtle changes in the myelin structure, there were no structural alterations in the myelin sheath of the sciatic and optic nerves in rat models of CIPN induced using cisplatin, paclitaxel or bortezomib (Gilardini et al., 2012). These findings mirror the findings of earlier work that used fixed tissues (spinal cord and DRGs) from rodents administered the same cancer chemotherapy agents (Cavaletti et al., 1995) as well as from humans with paclitaxel-induced CIPN (Postma et al., 1995). In patients with bortezomib-induced CIPN, approximately 50\% had pure small fiber neuropathy whereas the remainder had mixed small and large fiber involvement (Richardson et al., 2009).
In rat models of paclitaxel, cisplatin and bortezomib-induced CIPN, there were no clear-cut changes in the structure of internodal myelin (Gilardini et al., 2012). However, higher dosages of bortezomib were associated with an increased risk of peripheral nerve degeneration and possibly demyelination in contrast to lower dosages that nevertheless induced neuropathic pain behaviors (Zheng et al., 2012) (Table 1). In earlier work in patients administered paclitaxel, sural nerve biopsy revealed severe nerve fiber loss, axonal atrophy (with absence of axonal regeneration) and secondary demyelination (Sahenk et al., 1994). These peripheral nerve changes argue more for ganglionopathy than axonopathy as the most likely structural change in paclitaxel-induced neurotoxicity (Sahenk et al., 1994).

\section{SLOWING OF SNCV MAY NOT BE DUE TO DEMYELINATION OR DEGENERATION OF PERIPHERAL NERVE AXONS}

In CIPN, reduced sensory nerve conduction velocity (SNCV) (Gilardini et al., 2012; Xiao et al., 2012), can only be attributed reliably to myelinopathy if it is associated with preserved nerve compound action potentials (Gilardini et al., 2012). Unfortunately, the technical limitations of current neurophysiological methods do not allow the relative contributions of demyelination and axonal degeneration on reduced SNCV in CIPN to be assessed (Gilardini et al., 2012). In rats with docetaxelinduced CIPN, reduced levels of myelin and mRNA encoding myelin suggest that myelin is targeted in experimental peripheral neuropathies (Roglio et al., 2009). These findings are consistent with observations of taxane-induced axonal damage and secondary demyelination (Sahenk et al., 1994; Quasthoff and Hartung, 2002; Windebank and Grisold, 2008). The extent to which individual anticancer agents or treatment combinations induce differential structural changes in peripheral nerves, is currently unclear. This is a knowledge gap that requires systematic investigation in rodent models for comparison with the changes observed in skin biopsy specimens from patients with CIPN.

\section{IENF LOSS WITHOUT DEGENERATION OF PERIPHERAL NERVE AXONS AND ASSOCIATED WITH MITOCHONDRIAL DYSFUNCTION}

Unmyelinated fibers and terminal nerve arbors are major sites of cancer chemotherapy-induced neurotoxicity (Grisold et al., 2012) such that intraepidermal nerve fiber (IENF) loss or terminal arbor degeneration is proposed as a common lesion in various toxic neuropathies (Bennett et al., 2011; Zheng et al., 2012).

In a rodent model of paclitaxel-induced CIPN, significant IENF degeneration was not apparent by approximately 10 days after initiation of the paclitaxel treatment regimen $(2 \mathrm{mg} / \mathrm{kg}$ on 4 alternate days) with peak effects observed several days later (Xiao et al., 2011). IENF degeneration and the development of pain behavior appear to be linked as both have similar delays to onset and peak effects (Xiao et al., 2011). Using electron microscopy at the time of peak pain severity, there were no signs of axonal degeneration in the saphenous nerve of these animals at a level just below the knee joint (Flatters and Bennett, 2006). Additionally, upregulation of activating transcription factor-3 (ATF-3) expression, a marker of axonal injury (Tsujino et al., 2000), was not observed in the nuclei of afferent neurons (Flatters and Bennett, 2006). Similar findings have been observed in rat 
Table 1 | Effects of clinically used cancer chemotherapy agents on peripheral nerve structure in rodent models of CIPN.

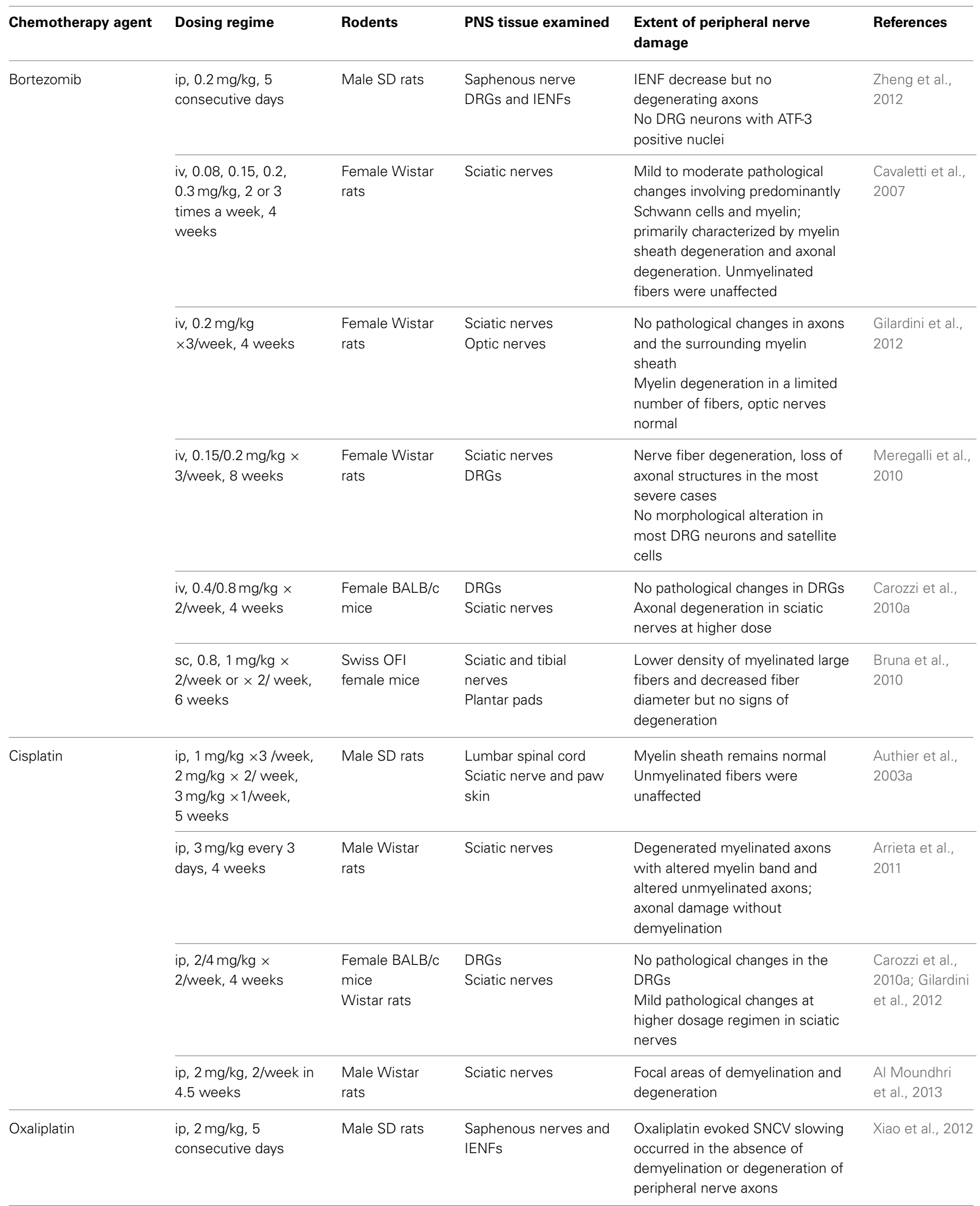


Table 1 | Continued

\begin{tabular}{|c|c|c|c|c|c|}
\hline Chemotherapy agent & Dosing regime & Rodents & PNS tissue examined & $\begin{array}{l}\text { Extent of peripheral nerve } \\
\text { damage }\end{array}$ & References \\
\hline & $\begin{array}{l}\text { ip, } 2 \mathrm{mg} / \mathrm{kg}, 4 \\
\text { alternate days }\end{array}$ & Male SD rats & Nerve fibers & Significantly fewer IENFs & $\begin{array}{l}\text { Boyette-Davis } \\
\text { and Dougherty, } \\
2011\end{array}$ \\
\hline & $\begin{array}{l}\text { ip, } 4 \mathrm{mg} / \mathrm{kg}, 2 / \text { week in } \\
4.5 \text { weeks }\end{array}$ & $\begin{array}{l}\text { Male Wistar } \\
\text { rats }\end{array}$ & Sciatic nerves & $\begin{array}{l}\text { Focal areas of demyelination and } \\
\text { degeneration }\end{array}$ & $\begin{array}{l}\text { Al Moundhri } \\
\text { et al., } 2013\end{array}$ \\
\hline Vincristine & $\begin{array}{l}\text { iv, } 50,100 \text { and } \\
150 \mu \mathrm{g} / \mathrm{kg} \text {, every } \\
\text { second day, up to five } \\
\text { injections }\end{array}$ & $\begin{array}{l}\text { Male SD } \\
\text { rats }\end{array}$ & Paw skin & $\begin{array}{l}\text { Myelin sheaths remained } \\
\text { unaffected }\end{array}$ & $\begin{array}{l}\text { Authier et al., } \\
2003 b\end{array}$ \\
\hline \multirow[t]{7}{*}{ Paclitaxel } & ip, single $32 \mathrm{mg} / \mathrm{kg}$ & Male SD rats & $\begin{array}{l}\text { Lumbar spinal cord, } \\
\text { Sciatic nerve and paw } \\
\text { skin }\end{array}$ & $\begin{array}{l}\text { Axonal degenerative changes } \\
\text { while Schwann cells and myelin } \\
\text { sheaths remained normal }\end{array}$ & $\begin{array}{l}\text { Authier et al., } \\
2000 b\end{array}$ \\
\hline & $\begin{array}{l}\text { ip, } 0.5,1,2,6 \text { or } \\
8 \mathrm{mg} / \mathrm{kg} \text {, } \\
4 \text { alternate days }\end{array}$ & Male SD rats & $\begin{array}{l}\text { DRGs } \\
\text { Sciatic nerves }\end{array}$ & $\begin{array}{l}\text { No degeneration, no DRG } \\
\text { neurons with ATF-3 positive nuclei } \\
\text { No degeneration of myelinated or } \\
\text { unmyelinated axons }\end{array}$ & $\begin{array}{l}\text { Polomano et al., } \\
\text { 2001; Flatters } \\
\text { and Bennett, } \\
\text { 2006; Bennett } \\
\text { et al., } 2011\end{array}$ \\
\hline & $\begin{array}{l}\text { ip, } 16 \mathrm{mg} / \mathrm{kg} \times 1 / \text { week, } \\
4 \text { weeks } \\
\text { iv, } 5,10,12.5 \mathrm{mg} / \mathrm{kg} \times \\
1 / \text { week, } 4 \text { weeks }\end{array}$ & $\begin{array}{l}\text { Female Wistar } \\
\text { rats }\end{array}$ & $\begin{array}{l}\text { Axons } \\
\text { (sciatic nerve) }\end{array}$ & $\begin{array}{l}\text { Most myelinated fibers have } \\
\text { normal histology, some fibers } \\
\text { show axonal degeneration }\end{array}$ & $\begin{array}{l}\text { Persohn et al., } \\
2005\end{array}$ \\
\hline & $\begin{array}{l}\text { ip, } 12.5 \mathrm{mg} / \mathrm{kg} \times \\
1 / \text { week, } \\
9 \text { weeks }\end{array}$ & $\begin{array}{l}\text { Female Wistar } \\
\text { rats }\end{array}$ & DRGs & $\begin{array}{l}\text { Increased immunohistochemical } \\
\text { staining for ATF-3 }\end{array}$ & $\begin{array}{l}\text { Jamieson et al., } \\
2007\end{array}$ \\
\hline & $\begin{array}{l}\text { iv, } 10 \mathrm{mg} / \mathrm{kg} \times 1 / \text { week, } \\
4 \text { weeks }\end{array}$ & $\begin{array}{l}\text { Female Wistar } \\
\text { rats }\end{array}$ & $\begin{array}{l}\text { Sciatic nerves } \\
\text { Optic nerves }\end{array}$ & $\begin{array}{l}\text { No pathological changes in axons } \\
\text { and surrounding myelin sheath }\end{array}$ & $\begin{array}{l}\text { Gilardini et al., } \\
2012\end{array}$ \\
\hline & $\begin{array}{l}\text { iv, } 18 \mathrm{mg} / \mathrm{kg} \text {, twice, } \\
\text { every } 3 \text { days }\end{array}$ & Male SD rats & $\begin{array}{l}\text { Trigeminal ganglia } \\
\text { DRGs }\end{array}$ & $\begin{array}{l}\text { Increased immunohistochemical } \\
\text { staining for ATF-3 }\end{array}$ & $\begin{array}{l}\text { Jimenez- } \\
\text { Andrade et al., } \\
2006\end{array}$ \\
\hline & $\begin{array}{l}\text { ip, } 4.5 \mathrm{mg} / \mathrm{kg} \\
25 \mathrm{mg} / \mathrm{kg} \text {, or } 60 \mathrm{mg} / \mathrm{kg}\end{array}$ & $\begin{array}{l}\text { Female } \\
\text { C57BL/6 } \\
\text { mice }\end{array}$ & Sciatic nerves & $\begin{array}{l}\text { Macrophage-mediated } \\
\text { demyelination, axons completely } \\
\text { stripped of their myelin sheaths } \\
\text { and surrounded by the cytoplasm } \\
\text { of debris-filled phagocytes in } \\
\text { some cases }\end{array}$ & Mo et al., 2012 \\
\hline
\end{tabular}


Table 1 | Continued

\begin{tabular}{|c|c|c|c|c|c|}
\hline Chemotherapy agent & Dosing regime & Rodents & PNS tissue examined & $\begin{array}{l}\text { Extent of peripheral nerve } \\
\text { damage }\end{array}$ & References \\
\hline & $\begin{array}{l}\text { ip, } 8 \text { or } 16 \mathrm{mg} / \mathrm{kg} \times \\
1 / \text { week, } \\
5 \text { weeks }\end{array}$ & $\begin{array}{l}\text { Female Wistar } \\
\text { rats }\end{array}$ & $\begin{array}{l}\text { Sciatic/peroneal } \\
\text { nerves and DRGs }\end{array}$ & $\begin{array}{l}\text { Decrease in number of large } \\
\text { myelinated fibers, but not due to } \\
\text { a reduction in myelin thickness, } \\
\text { mild axonal loss with minimal } \\
\text { demyelination }\end{array}$ & $\begin{array}{l}\text { Cavaletti et al., } \\
1995\end{array}$ \\
\hline & $\begin{array}{l}\text { ip, } 30 \mathrm{mg} / \mathrm{kg} \text { once or } \\
\text { several times at } \\
\text { different intervals }\end{array}$ & BDF1 mice & $\begin{array}{l}\text { Dorsal funiculus } \\
\text { Dorsal spinal roots } \\
\text { Peripheral nerves }\end{array}$ & $\begin{array}{l}\text { Nerve fiber degeneration } \\
\text { characterized by axonal and } \\
\text { myelin fragmentations and } \\
\text { phagocytosis }\end{array}$ & $\begin{array}{l}\text { Mimura et al., } \\
2000\end{array}$ \\
\hline
\end{tabular}

ATF, activating transcription factor; CGRP, calcitonin gene-related peptide; DRG, dorsal root ganglia; IENFs, intraepidermal nerve fibers; iV, intravenous injection; ip, intraperitoneal injection; SC, subcutaneous; SD, Sprague-Dawley; SNCV, sensory nerve conduction velocity.

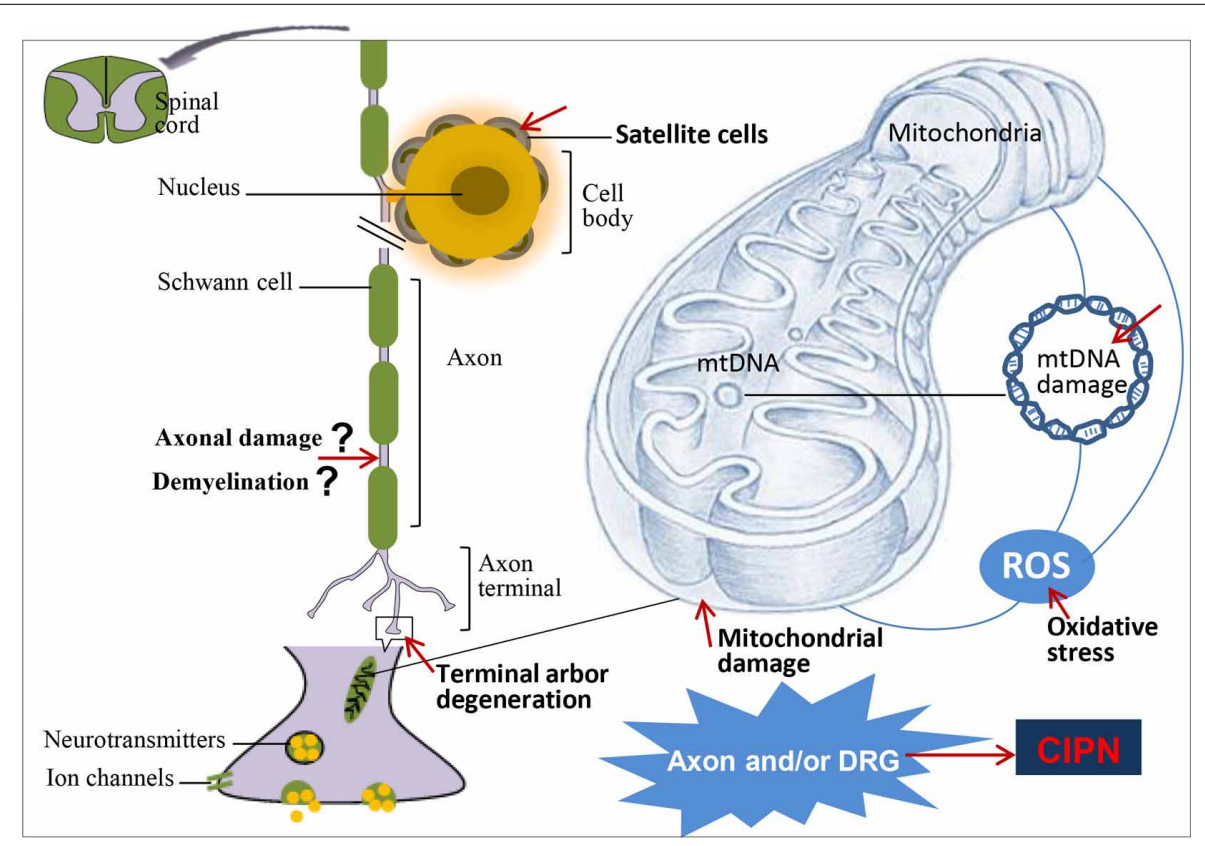

FIGURE 1 | CIPN pathogenesis and associated morphologic changes. The neurotoxic effects of cancer chemotherapy agents adversely affect multiple components of the peripheral nervous system (PNS) including axons and cell bodies of dorsal root ganglion (DRG) neurons to cause axonal damage (IENF loss/terminal arbor degeneration), mitochondrial damage and oxidative stress probably associated with inflammation. DRG neurons and their surrounding satellite cells show pathological changes including alterations in levels of expression of multiple ion channels (Xiao et al., 2007; Anand et al., 2010; Kaur et al., 2010; Descoeur et al., 2011), neurotransmitters (Tatsushima et al.,
2011), and their receptors (Carozzi et al., 2010b; Mihara et al., 2011), as well as altered gene expression (Alaedini et al., 2008). Mitochondrial dysfunction and IENF loss appear to be important pathobiological features of CIPN that are correlated directly with pain behaviors in rodent models (Flatters and Bennett, 2006; Zheng et al., 2012). Indeed, direct mitochondrial DNA (mtDNA) damage contributes to cisplatin-induced CIPN (Podratz et al., 2011). Myelinated fibers are damaged (Cata et al., 2006) possibly by preferential selection (Dougherty et al., 2004) but the extent to which demyelination is a key pathobiological event is currently unclear. models of vincristine, oxaliplatin and bortezomib-induced CIPN such that neuropathic pain behaviors were associated with IENF degeneration in the absence of peripheral nerve axonal degeneration (Aley et al., 1996; Tanner et al., 1998; Topp et al., 2000; Siau and Bennett, 2006; Bennett et al., 2011).
Clinically, there is IENF loss in patients with CIPN (BoyetteDavis et al., 2011; Giannoccaro et al., 2011) despite these individuals having normal peripheral nerve axon counts (Holland et al., 1998; Herrmann et al., 1999) and normal nerve conduction results (Periquet et al., 1999; Devigili et al., 2008; Løseth et al., 
2008). This led Holland et al. (1998) to coin the term "terminal axonopathy" that is akin to the more recently promulgated "terminal arbor degeneration" concept (Bennett et al., 2011). In patients, an increase in the swelling ratio of IENFs appeared to be predictive of a decrease in IENF density and this was correlated with the severity of painful neuropathy induced in the feet by paclitaxel (CIPN), diabetes, AIDS, and idiopathic neuropathy (Schmidt et al., 1997; Lauria et al., 2003). However, administration of much larger doses of cancer chemotherapy agents in rats, such as paclitaxel either as a single bolus $(12.5-32 \mathrm{mg} / \mathrm{kg})$ (Authier et al., 2000b; Jamieson et al., 2007) or as cumulative doses ( 8 and $16 \mathrm{mg} / \mathrm{kg}$ once-weekly for 5 weeks) (Cavaletti et al., 1995) or bortezomib at $2.4-4.8 \mathrm{mg} / \mathrm{kg}$ (Cavaletti et al., 2007; Meregalli et al., 2010; Gilardini et al., 2012), resulted in degeneration of peripheral nerve axons and DRG neurons, together with ATF-3 up-regulation in DRG neurons (Jamieson et al., 2007; Peters et al., 2007). Thus, the extent to which peripheral nerve axons are damaged by chemotherapy agents appear to be directly related to the dosing regimen (Table $\mathbf{1}$ ).

Comparatively high concentrations of paclitaxel are found in the DRGs relative to peripheral nerve and spinal cord (Herrmann et al., 1999), that may be underpinned by the fact that the subepidermal axon bundles in peripheral nerves lack a perineurium (a component of the blood-nerve barrier). Additionally, anterograde transport of paclitaxel from sensory neuron cell bodies to the IENFs would take time for toxic levels to be reached in the terminal arbors (Bennett et al., 2011). Such a lag period may potentially explain the coasting effect, i.e., the delay between treatment cessation relative to the loss of IENFs and the appearance of pain hypersensitivity (Bennett et al., 2011).

IENF degeneration and abnormal spontaneous discharge of primary afferent nerve fibers in rat models of CIPN may be underpinned by mitochondrial dysfunction and consequent energy deficiency (Boyette-Davis and Dougherty, 2011; Xiao et al., 2012; Zheng et al., 2012). Mitochondria are concentrated in regions of high metabolic demand (Chen and Chan, 2006; Mironov, 2007) such as sensory terminal boutons that are packed with mitochondria (Breathnach, 1977; Ribeiro-Da-Silva et al., 1991; Bennett et al., 2011). The high energy requirement of the intraepidermal terminal arbor is thought to be due, at least in part, to the constant degeneration and regeneration (remodeling) of the arbor in its ever changing microenvironment (Bennett et al., 2011). This is because the epidermis is in a continuous state of renewal with a total epidermal turnover time of approximately 45 days in humans (Bergstresser and Taylor, 1977).

\section{MITOCHONDRIAL DYSFUNCTION AND OXIDATIVE STRESS}

Mitochondria are the energy-generating structures in cells with their dysfunction implicated in the pathogenesis of cancer and a range of neurodegenerative diseases (Florea and Büsselberg, 2011). Abnormalities in mitochondrial structure and function in peripheral sensory nerve fibers are postulated as key CIPN mechanisms and appear to be correlated directly with pain behavior (Flatters and Bennett, 2006; Zheng et al., 2012). In multiple myeloma patients administered cycles of bortezomib in combination with dexamethasone, bortezomib toxicity on mitochondria resulted in impairment of the electrogenic
$\mathrm{Na}^{+}-\mathrm{K}^{+}$-ATPase-dependent pump resulting in axonal membrane depolarization that preceded axonal degeneration (Nasu et al., 2013). In patients with vincristine and bortezomibinduced CIPN, there were significant changes in the expression of genes involved in the control of mitochondrial function in myeloma plasma cells and peripheral blood (Broyl et al., 2010). Interestingly, exposure of cultured DRG neurons to cisplatin and paclitaxel in vitro induced mitochondrial damage that was reversed by pretreatment with the antioxidant, $\alpha$-lipoic acid (Melli et al., 2008). Additionally, the development of CIPN in rodent models (Table 2 ) and patients (Table 3 ) can be prevented by treatment with drugs that enhance mitochondrial function. Conversely, as mitochondrial poisons exacerbate neuropathic pain behaviors in rodent models of CIPN (Xiao and Bennett, 2012), CIPN appears to be linked to mitotoxicity (Figure 1).

\section{MITOTOXICITY \\ Direct mitochondrial DNA (mtDNA) damage}

Cisplatin forms adducts with mitochondrial DNA resulting in direct mitochondrial DNA (mtDNA) damage that is a novel mechanism for cisplatin-induced CIPN and is distinct from the established nuclear DNA (nDNA) damage pathway (Podratz et al., 2011). DRG neurons accumulate high levels of cisplatinDNA adducts both in vitro and in vivo (McDonald et al., 2005; Ta et al., 2006) such that the cisplatin concentration in the PNS is comparable with that in tumor tissue (Gregg et al., 1992; Screnci and McKeage, 1999; Melli et al., 2008).

Cisplatin-DNA adducts can be removed and DNA repaired by the nucleotide excision repair (NER) system that is present in nDNA (McDonald et al., 2005; Podratz et al., 2011), in contrast to mtDNA where the NER system is absent (Croteau et al., 1999). Hence, cisplatin-mtDNA adducts inhibit mtDNA replication and mtRNA transcription to cause mitochondrial degradation (Podratz et al., 2011) in DRG neurons.

\section{Increased mitochondrial swelling and vacuolation in peripheral nerve axons}

In rat models of paclitaxel, oxaliplatin and bortezomib-induced CIPN, the number of swollen and vacuolated mitochondria in the axons of A- and C-primary afferent sensory nerve fibers was significantly higher ( 37.3 and $152 \%$, respectively) than for vehicle-treated control rats (Xiao et al., 2011, 2012; Zheng et al., 2012). These changes resulted in mitochondrial dysfunction characterized by significant deficits in mitochondrial respiration and ATP production that were rescued by prophylactic treatment with acetyl-L-carnitine. The latter is an acetylated derivative of the natural amino acid, L-carnitine, that has an essential role in the transport of long-chain free fatty acids into mitochondria (Zheng et al., 2011, 2012). Interestingly, there was a relative sparing of mitochondria in the corresponding peripheral nerve Schwann cells (Flatters and Bennett, 2006; Zheng et al., 2011, 2012; Xiao and Bennett, 2012; Xiao et al., 2012).

In DRG satellite cells, bortezomib induced intracytoplasmic vacuolation characterized by damage to mitochondria and the endoplasmic reticulum (Cavaletti et al., 2007). These changes 
Table 2 | Summary of pharmacological agents that enhance mitochondrial function as well as prevent and/or alleviate CIPN in rodent models.

\begin{tabular}{|c|c|c|c|c|}
\hline Pharmacological agent & Rodent model & Efficacy outcome & Dose and route & References \\
\hline \multirow[t]{7}{*}{ Acetyl-L-carnitine (antioxidant) } & Paclitaxel & + (intervention) & 100 mg/kg, p.o. Daily × 10 & Flatters et al., 2006 \\
\hline & Paclitaxel & +(prophylactic) & 50 and $100 \mathrm{mg} / \mathrm{kg}$, p.o. Daily $\times 21$ & Flatters et al., 2006 \\
\hline & Paclitaxel & + (prophylactic and intervention) & 100 mg/kg, s.c. Daily & Ghirardi et al., 2005 \\
\hline & Vincristine & + (prophylactic and intervention) & 100 mg/kg, s.c. Daily & Ghirardi et al., 2005 \\
\hline & Cisplatin & + (prophylactic and intervention) & 100 mg/kg, s.c. Daily & Ghirardi et al., 2005 \\
\hline & Oxaliplatin & + (prophylactic and intervention) & 100 mg/kg, s.c. Daily & Orlando et al., 2005 \\
\hline & Oxaliplatin & + (prophylactic) & 100 mg/ml/kg, p.o. Daily & Xiao et al., 2012 \\
\hline \multirow[t]{2}{*}{ Olesoxime } & Paclitaxel & + (prophylactic) & 3 or 30 mg/kg, p.o. Daily & Xiao et al., 2009 \\
\hline & Oxaliplatin & + (prophylactic) & 30 mg/ml/kg, p.o. Daily & Xiao et al., 2012 \\
\hline Silibinin(antioxidant) & Oxaliplatin & + (prophylactic) & 100 mg/kg, p.o. Daily & Di Cesare Mannelli et al., 2012 \\
\hline Allopregnanolone & Oxaliplatin & + (prophylactic and intervention) & 2 or $4 \mathrm{mg} / \mathrm{kg}$, Every 2 or 4 days & Meyer et al., 2011 \\
\hline
\end{tabular}

p.o., per os; s.c., subcutaneous.

Table 3 | Clinical trial evidence for the role antioxidants in the relief of CIPN.

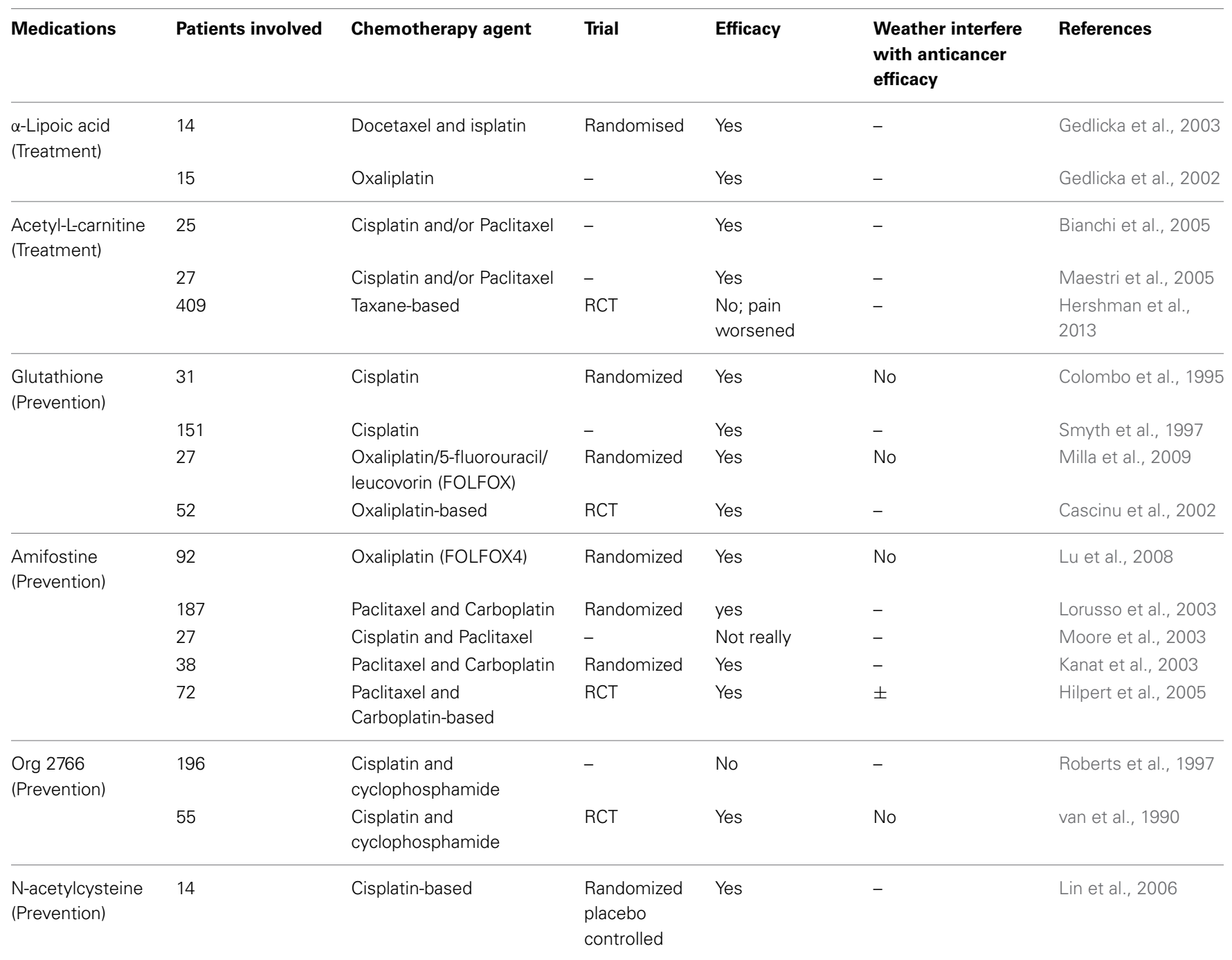

RCT, Randomized, Double-Blind, Placebo-Controlled Trial. 
appear to be underpinned by activation of the mitochondrialbased apoptotic pathway including caspase activation (Broyl et al., 2010; Lee et al., 2012) as well as dysregulation of calcium homeostasis (Landowski et al., 2005). Paclitaxel-induced mitochondrial damage was confined to the axons of primary afferent sensory with sparing of motor neurons (Xiao et al., 2011). The high and persistent exposure of primary sensory neuron cell bodies in the DRGs to paclitaxel may contribute to this selective effect (Xiao et al., 2011).

\section{Opening of the MPTP and dysregulation of calcium homoeostasis}

Paclitaxel opens the mitochondrial permeability transition pore (mPTP), a multi-molecular complex containing a voltagedependent anion channel that induces mitochondrial calcium release (Kidd et al., 2002; Flatters and Bennett, 2006). AcetylL-carnitine can prevent mPTP opening (Pastorino et al., 1993) and is associated with a reduction in paclitaxel, oxaliplatin and bortezomib-induced CIPN when administered prophylactically in rodents (Jin et al., 2008; Bujalska and Makulska-Nowak, 2009; Carozzi et al., 2010b; Xiao et al., 2012; Zheng et al., 2012).

Mitochondria have a large calcium buffering capacity and so impaired calcium uptake or increased calcium leakage from mitochondrial stores may have a pathological role in CIPN (Jaggi and Singh, 2012). This notion is supported by the fact that vincristineinduced neurotoxicity in rats was reversed by drugs that reduce elevated intra-neuronal calcium concentrations (Muthuraman et al., 2008; Kaur et al., 2010). In other work, increased expression levels of the $\alpha_{2} \delta$ subunit of voltage-gated $\mathrm{Ca}^{2+}$ channels in the DRGs were correlated with the development of mechanical allodynia (Luo et al., 2001). Conversely, drugs that bind to the $\alpha_{2} \delta$ subunit such as gabapentin (Flatters and Bennett, 2004; Xiao et al., 2007) and pregabalin (Saif et al., 2010; Nakashima et al., 2012; Peng et al., 2012), as well as the L-type calcium channel blocker, lercanidipine (Saha et al., 2012), showed efficacy for prevention of CIPN in rodent models and patients (Nguyen and Lawrence, 2004; Saif et al., 2010; Nakashima et al., 2012).

A retrospective review of 69 patients administered oxaliplatin concluded that calcium channel blockers reduce CIPN (Tatsushima et al., 2013). Although intravenous $\mathrm{Ca}^{2+} / \mathrm{Mg}^{2+}$ infusions reportedly attenuate the development of oxaliplatin-induced CIPN without compromising cancer treatment efficacy (Wolf et al., 2008; Kurniali et al., 2010; Wen et al., 2013), there are lingering concerns regarding a negative effect on cancer chemotherapy treatment efficacy. Hence, this needs to be evaluated for each class of cancer chemotherapy agent (Kurniali et al., 2010).

\section{OXIDATIVE STRESS}

In a rat model of oxaliplatin-induced neuropathy, markers of oxidative stress including lipid peroxidation, carbonylated proteins, and DNA oxidation increased in the systemic circulation, the sciatic nerve and the lumbar spinal cord (Di Cesare Mannelli et al., 2012), with these changes prevented by antioxidant treatment (Di Cesare Mannelli et al., 2012; Nasu et al., 2013). Similarly, production of reactive oxygen species (ROS) was increased by cisplatin (Florea and Büsselberg, 2011), and bortezomib (Wang et al., 2011). In patients receiving docetaxel for the treatment of cancer, the occurrence of grade $\geq 2 \mathrm{CIPN}$ was more frequent in individuals homozygous for GSTP $1{ }^{105}$ Ile allele, that encodes glutathione S-transferase pi 1 (GSTP1), an enzyme involved in the regulation of oxidative stress (Mir et al., 2009).

A role for oxidative stress in the pathobiology of CIPN is supported by multiple in vitro and in vivo studies showing that antioxidants have neuroprotective effects in CIPN (Table 2). In particular, the non-specific ROS scavenger, phenyl N-tertbutylnitrone (PBN), administered according to an intervention protocol in rats administered paclitaxel, attenuated development of mechanical (Kim et al., 2010) and cold hypersensitivity in the hindpaws (Fidanboylu et al., 2011). Conversely, for rats administered auranofin, a compound that increased oxidative stress, oxaliplatin and paclitaxel-induced neuropathic pain behaviors were exacerbated (Xiao and Bennett, 2012). Furthermore, as the superoxide-specific scavenger, TEMPOL (4-hydroxy-2,2,6,6-tetramethylpiperidine-1-oxyl) neither alleviated established paclitaxel-induced CIPN nor prevented its development in rodents, ROS but not superoxide radicals alone, are implicated in CIPN pathogenesis (Fidanboylu et al., 2011).

Although a benefit of antioxidants for the treatment and/or prevention of CIPN has been shown in multiple clinical studies (Table 3), most did not report on their impact on anticancer efficacy, and so this is a knowledge gap.

Increased spinal dorsal horn levels of peroxynitrite in rats with paclitaxel-induced CIPN (Doyle et al., 2012) implicate a role for reactive nitrogen species (RNS) in CIPN pathogenesis (Kamei et al., 2005; Mihara et al., 2011). Augmented peroxynitrite production may occur via two mechanisms with the first involving activation of nitric oxide synthase and NADPH oxidase to induce formation of the peroxynitrite precursors, $\mathrm{NO}$ and SO (Doyle et al., 2012). The second involves inactivation of the enzyme (manganese superoxide dismutase) that catalyzes peroxynitrite degradation (Doyle et al., 2012). This latter mechanism is supported by observations that peroxynitrite decomposition catalysts (FeTMPyP ${ }^{5+}$ and MnTE-2-PyP ${ }^{5+}$ ) prevented development of neuropathic pain behaviors in rat models of paclitaxel, oxaliplatin and bortezomib-induced CIPN (Doyle et al., 2012; Janes et al., 2013).

CIPN-induced nitro-oxidative stress results in increased production of proinflammatory cytokines (TNF- $\alpha$ and IL-1 $\beta$ ), reduced production of anti-inflammatory cytokines (IL-10 and IL-4), as well as post-translational nitration of glutamate transporters and glutamine synthetase in astrocytes, the net result of which is enhanced pro-nociceptive glutamatergic signaling (Doyle et al., 2012). Treatment strategies that shift the balance in favor of anti-inflammatory cytokines have potential for slowing the development and progression of peripheral neuropathy in patients receiving cancer chemotherapy drugs (Wang et al., 2012).

\section{LOSS OF HEAT SENSITIVITY IN CIPN DIVERSE RESULTS OF HEAT SENSITIVITY IN CIPN}

Primary afferent nerve fibers affected by cancer chemotherapy drug treatment regimens often exhibit both positive and negative sensory phenomena resulting in altered nociceptive thresholds (Nahman-Averbuch et al., 2011). Increased nociceptive thresholds may develop due to nerve fiber loss whereas reduced 
nociceptive thresholds may develop as a result of peripheral and central sensitization (Nahman-Averbuch et al., 2011).

In general, there is heat hypoalgesia or a loss of heat sensitivity in patients with CIPN (Dougherty et al., 2004; Cata et al., 2006; Attal et al., 2009; Nahman-Averbuch et al., 2011) as well as in most rodent models of this condition (Authier et al., 2000a, 2003a; Fischer et al., 2001; Cata et al., 2006, 2008; Garcia et al., 2008; Hori et al., 2010; Xiao et al., 2012; Zheng et al., 2012). Additionally, cold allodynia is a characteristic symptom of painful CIPN in patients (Cata et al., 2006) as well as in rodent models (Authier et al., 2003a,b; Cata et al., 2006; Xiao et al., 2012).

\section{LOSS OF HEAT SENSITIVITY MAY RESULT FROM SENSITIZATION/DESENSITIZATION OF TRPV1}

Loss of heat sensibility may be due to myelinated A-fiber damage and loss of transient receptor potential vanilloid 1 (TRPV1)expression (Woodbury et al., 2004) C-fibers (Dougherty et al., 2004).

A small increase in ROS production activates transcriptional machinery to enhance TRPV1 expression levels in C-fibers (Suzukawa et al., 2000; Kishi et al., 2002; Schmeichel et al., 2003). Additionally, nerve growth factor (NGF) facilitates increased TRPV1 expression by nociceptive C-fibers and directly increases the number of neurons that respond to noxious heat (Stucky and Lewin, 1999; Amaya et al., 2004). Enhanced thermal sensitivity results from sensitization (phosphorylation) of TRPV1, transduced by protein kinase C (PKC) (Kamei et al., 2001; Di Marzo et al., 2002; Hong and Wiley, 2005) and/or mitogen-activated protein kinases (MAPK) (Ji et al., 2002; Clapham, 2003). In the DRGs and hindpaw skin of hyperalgesic and hypoalgesic mice, TRPV1 expression levels are increased and decreased, respectively (Pabbidi et al., 2008). Thermal hypoalgesia may be underpinned by reduced TRPV1 expression and function, that in turn may lead to more serious complications (Pabbidi et al., 2008).

Other TRP channels implicated in the pathogenesis of CIPN include TRPA1 that is expressed by nociceptors and is activated by oxidative stress. The transient benefit of the TRPA1 antagonist HC-030031 in mice with bortezomib or oxaliplatininduced CIPN, suggests a role for early activation/sensitization of TRPA1 by oxidative stress by-products in establishment of CIPN (Trevisan et al., 2013). Additionally, TRPV4 may contribute to paclitaxel-induced mechanical hypersensitivity in CIPN (Alessandri-Haber et al., 2004), whereas TRPA1 and TRPM8 over-expression were induced in the DRGs by oxaliplatin (Anand et al., 2010; Descoeur et al., 2011). Cisplatin and oxaliplatininduced neurotoxicity of DRG neurons in rats results in p38 MAPK and ERK1/2 activation as well as a reduction in JNK/Sapk phosphorylation (Scuteri et al., 2009, 2010). Apart from the foregoing, a broad array of other molecular mechanisms have been implicated in the pathobiology of CIPN and these have been reviewed elsewhere (Jaggi and Singh, 2012; Wang et al., 2012) and are summarized in Table 4.

\section{BETWEEN CANCER CHEMOTHERAPY AGENT DIFFERENCES IN THE PATHOBIOLOGY OF CIPN}

CIPN affects sensory nerves predominantly; while motor, autonomic or CNS (Schlegel, 2011) involvement is rare (Grisold et al., 2012). Sensory nerves allow the perception of touch, pain, temperature (small fiber); position, and vibration (large fiber) (Wilkes, 2007). The persistent cumulative injury caused by cancer chemotherapy agents most often affects sensory nerve cell bodies in the DRGs (e.g., cisplatin) and/or the afferent and efferent axons lying outside the spinal cord (e.g., paclitaxel, oxaliplatin) (Quasthoff and Hartung, 2002).

It is generally assumed that platinum compounds irreversibly bind to DNA thereby inducing apoptosis of primary sensory neurons (Velasco and Bruna, 2010). Antitubulins (paclitaxel, docetaxel and vincristine) bind to microtubules, interrupt axonal transport, target the soma of sensory neurons as well as nerve axons, to induce neuronal death (Bennett, 2010; Cavaletti and Marmiroli, 2010; Velasco and Bruna, 2010). In cultured rat DRG neurons, paclitaxel increased the release of the pro-nociceptive neuropeptide, substance $\mathrm{P}$, whereas oxaliplatin did not; the extent to which this difference contributes to differences in paclitaxel and oxaliplatin-induced peripheral nerve neurotoxicity, remains to be determined (Tatsushima et al., 2011). In patients with CIPN, sensory testing shows that peripheral nerve abnormalities appear to have distinct features depending upon the cancer chemotherapeutic agent involved (Cata et al., 2006), but the mechanistic basis remains unclear (Gilchrist, 2012).

Conversely, it is also likely that one or more pathobiologic mechanisms are shared among anticancer agents (Dougherty et al., 2004; Grisold et al., 2012; Zheng et al., 2012). For example, nerve biopsies from rodents and patients administered cisplatin (Dougherty et al., 2004), paclitaxel, oxaliplatin, vincristine, and bortezomib show similar morphological changes (loss of IENFs) even though these compounds have different neurotoxic targets (Flatters and Bennett, 2006; Bennett et al., 2011; Boyette-Davis et al., 2011; Burakgazi et al., 2011; Pachman et al., 2011; Xiao et al., 2012; Zheng et al., 2012). Additionally, mitotoxicity appears to be a factor in common in the pathobiology of CIPN induced by the taxane, paclitaxel, the platinum-complex agent, oxaliplatin, and the proteasome-inhibitor, bortezomib, in rodent models (Zheng et al., 2011, 2012; Xiao et al., 2012).

Although CIPN may share mediators in common with other types of neuropathic pain, the disparity in efficacy of anti-neuropathic agents suggests underlying mechanistic differences (Farquhar-Smith, 2011). For example, NGF deficiency in peripheral nerves is a phenomenon in common between cisplatin-induced CIPN (Cavaletti et al., 2002) and early diabetic neuropathy (Anand, 2004). Hypersensitivity to heat is common in the CCI-rat model of neuropathic pain, but it is very minor or absent in rat models of CIPN (Bennett, 2010) and in patients with either CIPN (Dougherty et al., 2004; Hershman et al., 2011) or diabetic neuropathy (Sorensen et al., 2006; Nahman-Averbuch et al., 2011). Such dissociations indicate that the pathophysiological mechanisms responsible for peripheral nerve injury and neuropathic pain are at least in part dependent upon the cause of the nerve injury (Bennett, 2010).

\section{CONCLUSION}

CIPN is characterized by multiple sensory changes including the development of (i) mechanical allodynia, whereby light pressure or touch that would normally be perceived as innocuous, 
Table 4 | Molecular mechanisms implicated in the pathogenesis of CIPN.

\begin{tabular}{|c|c|c|c|}
\hline Chemotherapy agents & $\begin{array}{l}\text { Rodent CIPN models and } \\
\text { human studies }\end{array}$ & Mechanism & References \\
\hline $\begin{array}{l}\text { Cisplatin } \\
\text { Oxaliplatin }\end{array}$ & $\begin{array}{l}\text { Male C57BL6 mice } \\
\text { Female Wistar } \\
\text { rats-cultured DRGs }\end{array}$ & $\begin{array}{l}\text { Up-regulation of TRPV1, TRPA1 } \\
\text { and TRPM8 } \\
\text { TRPM8 and/or TRPA1 } \\
\text { over-expression; respond to cold } \\
\text { allodynia }\end{array}$ & $\begin{array}{l}\text { Anand et al., 2010; Ta et al., } \\
\text { 2010; } \\
\text { Descoeur et al., 2011; } \\
\text { Goswami, } 2012\end{array}$ \\
\hline $\begin{array}{l}\text { Vincristine } \\
\text { Paclitaxel }\end{array}$ & Male SD rats & $\begin{array}{l}\text { Calcium increase either by influx } \\
\text { of extracellular } \mathrm{Ca}^{2+} \text { or release } \\
\text { from mitochondrial intracellular } \\
\text { stores, binding to } \alpha_{2} \delta \text { subunit of } \\
\mathrm{Ca}^{2+} \text { channel; decreased calcium } \\
\text { flux }\end{array}$ & $\begin{array}{l}\text { Xiao et al., 2007; Kaur et al., } \\
2010\end{array}$ \\
\hline
\end{tabular}

\begin{tabular}{ll}
\hline Paclitaxel & Human neuroblastoma cell \\
& line, SHSY-5Y
\end{tabular}

Activation of calpain, degradation Benbow et al., 2012

of neuronal calcium sensor

(NCS-1), and loss of intracellular

calcium signaling

\begin{tabular}{|c|c|c|c|}
\hline $\begin{array}{l}\text { Paclitaxel } \\
\text { Vincristine } \\
\text { Cisplatin } \\
\text { Oxaliplatin } \\
\text { Bortezomib }\end{array}$ & $\begin{array}{l}\text { Female/male Wistar rats } \\
\text { Male SD rats }\end{array}$ & $\begin{array}{l}\text { NMDA receptor antagonists } \\
\text { antagonize CIPN in prevention but } \\
\text { not intervention protocol or only } \\
\text { at high doses }\end{array}$ & $\begin{array}{l}\text { Pascual et al., 2010; Mihara } \\
\text { et al., } 2011\end{array}$ \\
\hline $\begin{array}{l}\text { Oxaliplatin } \\
\text { Cisplatin } \\
\text { Vincristine }\end{array}$ & $\begin{array}{l}\text { Male mice- C57BL6J } \\
\text { Male SD rats }\end{array}$ & DNA damage & $\begin{array}{l}\text { Brederson et al., 2012; Ta } \\
\text { et al., } 2013\end{array}$ \\
\hline Oxaliplatin & Male SD rats & $\begin{array}{l}\text { Increase in PKC activity in } \\
\text { supra-spinal regions }\end{array}$ & Norcini et al., 2009 \\
\hline Paclitaxel but Not Oxaliplatin & $\begin{array}{l}\text { Male SD rats- cultured } \\
\text { DRG }\end{array}$ & $\begin{array}{l}\text { Increased release of substance P } \\
\text { and altered CGRP and } \\
\text { somatostatin release }\end{array}$ & Tatsushima et al., 2011 \\
\hline Oxaliplatin & $\begin{array}{l}\text { Patients } \\
\text { Rats }\end{array}$ & $\begin{array}{l}\text { Dysfunction of axonal } \mathrm{Na}^{+} \\
\text {channels } \\
\text { Dysfunction of axonal } \mathrm{K}^{+} \text {channels }\end{array}$ & $\begin{array}{l}\text { Park et al., 2011; } \\
\text { Kagiava et al., } 2013\end{array}$ \\
\hline Vincristine & Female Inbred C57BL mice & $\begin{array}{l}\text { Increase in } 5-\mathrm{HT}_{2 \mathrm{~A}} \text { receptors in } \\
\text { dorsal horn and } \mathrm{DRGs}\end{array}$ & Hansen et al., 2011 \\
\hline Paclitaxel & Male C57BL/6 mice & $\begin{array}{l}\text { Antagonists of Kinin B1 and B2 } \\
\text { receptors attenuate CIPN }\end{array}$ & Costa et al., 2011 \\
\hline
\end{tabular}




\section{Table 4 | Continued}

\begin{tabular}{|c|c|c|c|}
\hline Chemotherapy agents & $\begin{array}{l}\text { Rodent CIPN models and } \\
\text { human studies }\end{array}$ & Mechanism & References \\
\hline Oxaliplatin & Patients & $\begin{array}{l}\text { Integrin beta- } 3 \text { L33P is related } \\
\text { to CIPN severity but not the } \\
\text { development of CIPN }\end{array}$ & Antonacopoulou et al., 2010 \\
\hline $\begin{array}{l}\text { Paclitaxel } \\
\text { Cisplatin }\end{array}$ & Male SD rats & Inflammation & $\begin{array}{l}\text { Alaedini et al., 2008; Wang } \\
\text { et al., } 2012\end{array}$ \\
\hline $\begin{array}{l}\text { Taxol } \\
\text { Oxaliplatin }\end{array}$ & Balb/c mice & $\begin{array}{l}\text { Increased glial fibrillary acidic } \\
\text { protein expression in satellite } \\
\text { glial cells, and gap } \\
\text { junction-mediated coupling } \\
\text { between satellite glial cells }\end{array}$ & Warwick and Hanani, 2013 \\
\hline \multirow{2}{*}{ Oxaliplatin } & & $\begin{array}{l}\text { Activation of drug transporters } \\
\text { (nervous system transporters } \\
\text { including glutamate, copper } \\
\text { transporters, etc.) }\end{array}$ & Ceresa and Cavaletti, 2011 \\
\hline & & Patient's genetic background & $\begin{array}{l}\text { Windebank and Grisold, 2008; } \\
\text { Broyl et al., 2010; Grisold } \\
\text { et al., } 2012\end{array}$ \\
\hline
\end{tabular}

CGRP, Calcitonin gene related peptide; IENFs, intraepidermal nerve fibers; MAPK, mitogen activated protein kinase; NMDA (N-methyl-D-aspartate) receptors; TRPV, transient receptor potential vanilloid.

evokes pain, (ii) cold allodynia whereby cold temperature evokes a painful sensation, (iii) slowing of SNCV, and (iv) loss of heat sensitivity.

Although the precise pathobiology of CIPN remains to be fully elucidated, recent research implicates "terminal arbor degeneration" (Bennett et al., 2011) and the associated mitochondrial dysfunction and mitotoxicity (Podratz et al., 2011; Zheng et al., 2012) as well as oxidative stress (Nasu et al., 2013). Additional investigation is required to better define subtle between-chemotherapy agent differences in the pathogenesis of CIPN as a means for enhancing rational discovery of novel treatments with potential to prevent and/or attenuate the development of CIPN.

\section{REFERENCES}

Alaedini, A., Xiang, Z., Kim, H., Sung, Y. J., and Latov, N. (2008). Up-regulation of apoptosis and regeneration genes in the dorsal root ganglia during cisplatin treatment. Exp. Neurol. 210, 368-374. doi: 10.1016/j.expneurol.2007. 11.018

Alessandri-Haber, N., Dina, O. A., Yeh, J. J., Parada, C. A., Reichling, D. B., and Levine, J. D. (2004). Transient receptor potential vanilloid 4 is essential in chemotherapy-induced neuropathic pain in the rat. J. Neurosci. $24,4444-4452$. doi: 10.1523/JNEUROSCI.0242-04.2004

Aley, K. O., Reichling, D. B., and Levine, J. D. (1996). Vincristine hyperalgesia in the rat: a model of painful vincristine neuropathy in humans. Neuroscience 73 , 259-265. doi: 10.1016/0306-4522(96)00020-6

Al Moundhri, M. S., Al-Salam, S., Al Mahrouqee, A., Beegam, S., and Ali, B. H. (2013). The effect of curcumin on oxaliplatin and cisplatin neurotoxicity in rats: some behavioral, biochemical, and histopathological studies. J. Med. Toxicol. 9 , 25-33. doi: 10.1007/s13181-012-0239-x

Amaya, F., Shimosato, G., Nagano, M., Ueda, M., Hashimoto, S., Tanaka, Y., et al. (2004). NGF and GDNF differentially regulate TRPV1 expression that contributes to development of inflammatory thermal hyperalgesia. Eur. J. Neurosci. 20, 2303-2310. doi: 10.1111/j.1460-9568.2004. 03701.x

Anand, P. (2004). "Neurotrophic factors and their receptors in human sensory neuropathies," in Ngf and Related Molecules in Health and Disease, ed L. C. L. Aloe (Italy: Elsevier), 477-492.

Anand, U., Otto, W. R., and Anand, P. (2010). Sensitization of capsaicin and icilin responses in oxaliplatin treated adult rat DRG neurons. Mol. Pain 6. doi: 10.1186/1744-8069-1186-1182

Antonacopoulou, A. G., Argyriou, A. A., Scopa, C. D., Kottorou, A., Kominea, A., Peroukides, S., et al. (2010). Integrin beta-3 L33P: a new insight into the pathogenesis of chronic oxaliplatin-induced peripheral neuropathy? Eur. J. Neurol. 17, 963-968. doi: 10.1111/j.1468-1331.2010.02966.x

Argyriou, A. A., Cavaletti, G., Briani, C., Velasco, R., Bruna, J., Campagnolo, M., et al. (2013). Clinical pattern and associations of oxaliplatin acute neurotoxicity: a prospective study in 170 patients with colorectal cancer. Cancer 119, 438-444. doi: $10.1002 /$ cncr.27732

Arrieta, O., Hernandez-Pedro, N., Fernandez-Gonzalez-Aragon, M. C., SaavedraPerez, D., Campos-Parra, A. D., Rios-Trejo, M. A., et al. (2011). Retinoic acid reduces chemotherapy-induced neuropathy in an animal model and patients with lung cancer. Neurology 77, 987-995. doi: 10.1212/WNL.0b013e31822 $\mathrm{e} 045 \mathrm{c}$

Attal, N., Bouhassira, D., Gautron, M., Vaillant, J. N., Mitry, E., Lepere, C., et al. (2009). Thermal hyperalgesia as a marker of oxaliplatin neurotoxicity: a prospective quantified sensory assessment study. Pain 144, 245-252. doi: 10.1016/j.pain.2009.03.024 
Authier, N., Fialip, J., Eschalier, A., and Coudore, F. (2000a). Assessment of allodynia and hyperalgesia after cisplatin administration to rats. Neurosci. Lett. 291, 73-76. doi: 10.1016/S0304-3940(00)01373-2

Authier, N., Gillet, J.-P., Fialip, J., Eschalier, A., and Coudore, F. (2000b). Description of a short-term Taxol o-induced nociceptive neuropathy in rats. Brain Res. 887, 239-249. doi: 10.1016/S0006-8993(00)02910-3

Authier, N., Gillet, J.P., Fialip, J., Eschalier, A., and Coudore, F. (2003a). An animal model of nociceptive peripheral neuropathy following repeated cisplatin injections. Exp. Neurol. 182, 12-20. doi: 10.1016/S0014-4886(03)00003-7

Authier, N., Gillet, J. P., Fialip, J., Eschalier, A., and Coudore, F. (2003b). A new animal model of vincristine-induced nociceptive peripheral neuropathy. Neurotoxicology 24, 797-805. doi: 10.1016/S0161-813X(03)00043-3

Balayssac, D., Cayre, A., Authier, N., Bourdu, S., Penault-Llorca, F., Gillet, J. P., et al. (2005). Patterns of P-glycoprotein activity in the nervous system during vincristine-induced neuropathy in rats. J. Peripher. Nerv. Syst. 10, 301-310. doi: 10.1111/j.1085-9489.2005.10308.x

Balayssac, D., Ferrier, J., Descoeur, J., Ling, B., Pezet, D., Eschalier, A., et al. (2011). Chemotherapy-induced peripheral neuropathies: from clinical relevance to preclinical evidence. Expert Opin. Drug Saf. 10, 407-417. doi: 10.1517/14740338.2011.543417

Benbow, J. H., Mann, T., Keeler, C., Fan, C. P., Hodsdon, M. E., Lolis, E., et al. (2012). Inhibition of paclitaxel-induced decreases in calcium signaling. J. Biol. Chem. 287, 37907-37916. doi: 10.1074/jbc.M112.385070

Bennett, G. J. (2010). Pathophysiology and animal models of cancer-related painful peripheral neuropathy. Oncologist 15, 9-12. doi: 10.1634/theoncologist.2009S503

Bennett, G. J., Liu, G. K., Xiao, W. H., Jin, H. W., and Siau, C. (2011). Terminal arbor degeneration - a novel lesion produced by the antineoplastic agent paclitaxel. Eur. J. Neurosci. 33, 1667-1676. doi: 10.1111/j.1460-9568.2011.07652.x

Bergstresser, P. R., and Taylor, J. R. (1977). Epidermal 'turnover time'-a new examination. Br. J. Dermatol. 96, 503-506. doi: 10.1111/j.1365-2133.1977.tb07152.x

Bianchi, G., Vitali, G., Caraceni, A., Ravaglia, S., Capri, G., Cundari, S., et al. (2005). Symptomatic and neurophysiological responses of paclitaxel- or cisplatininduced neuropathy to oral acetyl-L-carnitine. Eur. J. Cancer 41, 1746-1750. doi: 10.1016/j.ejca.2005.04.028

Boland, B. A., Sherry, V., and Polomano, R. C. (2010). Chemotherapy-induced peripheral neuropathy in cancer survivors. Oncol. Nurse Edn. 24, 33-38, 42-43.

Boyette-Davis, J., and Dougherty, P. M. (2011). Protection against oxaliplatininduced mechanical hyperalgesia and intraepidermal nerve fiber loss by minocycline. Exp. Neurol. 229, 353-357. doi: 10.1016/j.expneurol.2011.02.019

Boyette-Davis, J., Xin, W., Zhang, H., and Dougherty, P. M. (2011). Intraepidermal nerve fiber loss corresponds to the development of Taxol-induced hyperalgesia and can be prevented by treatment with minocycline. Pain 152, 308-313. doi: 10.1016/j.pain.2010.10.030

Breathnach, A. S. (1977). Electron microscopy of cutaneous nerves and receptors. J. Invest. Dermatol. 69, 8-26. doi: 10.1111/1523-1747.ep12497857

Brederson, J. D., Joshi, S. K., Browman, K. E., Mikusa, J., Zhong, C., Gauvin, D., et al. (2012). PARP inhibitors attenuate chemotherapy-induced painful neuropathy. J. Peripher. Nerv. Syst. 17, 324-330. doi: 10.1111/j.1529-8027.2012. 00413.x

Broyl, A., Corthals, S. L., Jongen, J. L. M., van der Holt, B., Kuiper, R., de Knegt, Y., et al. (2010). Mechanisms of peripheral neuropathy associated with bortezomib and vincristine in patients with newly diagnosed multiple myeloma: a prospective analysis of data from the HOVON-65/GMMG-HD4 trial. Lancet Oncol. 11, 1057-1065. doi: 10.1016/S1470-2045(10)70206-0

Bruna, J., Udina, E., Alé, A., Vilches, J. J., Vynckier, A., Monbaliu, J., et al. (2010). Neurophysiological, histological and immunohistochemical characterization of bortezomib-induced neuropathy in mice. Exp. Neurol. 223, 599-608. doi: 10.1016/j.expneurol.2010.02.006

Bujalska, M., and Makulska-Nowak, H. (2009). Bradykinin receptors antagonists and nitric oxide synthase inhibitors in vincristine and streptozotocin induced hyperalgesia in chemotherapy and diabetic neuropathy rat model. Neuro Endocrinol. Lett. 30, 144-152.

Burakgazi, A. Z., Messersmith, W., Vaidya, D., Hauer, P., Hoke, A., and Polydefkis, M. (2011). Longitudinal assessment of oxaliplatin-induced neuropathy. Neurology 77, 980-986. doi: 10.1212/WNL.0b013e31822cfc59

Burton, A. W., Fanciullo, G. J., Beasley, R. D., and Fisch, M. J. (2007). Chronic pain in the cancer survivor: a new frontier. Pain Med. 8, 189-198. doi: 10.1111/j.15264637.2006.00220.x
Carozzi, V. A., Canta, A., Oggioni, N., Sala, B., Chiorazzi, A., Meregalli, C., et al. (2010a). Neurophysiological and neuropathological characterization of new murine models of chemotherapy-induced chronic peripheral neuropathies. Exp. Neurol. 226, 301-309. doi: 10.1016/j.expneurol.2010.09.004

Carozzi, V. A., Chiorazzi, A., Canta, A., Lapidus, R. G., Slusher, B. S., Wozniak, K. M., et al. (2010b). Glutamate carboxypeptidase inhibition reduces the severity of chemotherapy-induced peripheral neurotoxicity in rat. Neurotox. Res. 17, 380-391. doi: 10.1007/s12640-009-9114-1

Cascinu, S., Catalano, V., Cordella, L., Labianca, R., Giordani, P., Baldelli, A. M., et al. (2002). Neuroprotective effect of reduced glutathione on oxaliplatin-based chemotherapy in advanced colorectal cancer: a randomized, double-blind, placebo-controlled trial. J. Clin. Oncol. 20, 3478-3483. doi: 10.1200/JCO.2002.07.061

Cata, J. P., Weng, H. R., Burton, A. W., Villareal, H., Giralt, S., and Dougherty, P. M. (2007). Quantitative sensory findings in patients with bortezomib-induced pain. J. Pain 8, 296-306. doi: 10.1016/j.jpain.2006.09.014

Cata, J. P., Weng, H. R., and Dougherty, P. M. (2008). Behavioral and electrophysiological studies in rats with cisplatin-induced chemoneuropathy. Brain Res. 1230, 91-98. doi: 10.1016/j.brainres.2008.07.022

Cata, J. P., Weng, H. R., Lee, B. N., Reuben, J. M., and Dougherty, P. M. (2006). Clinical and experimental findings in humans and animals with chemotherapyinduced peripheral neuropathy. Minerva Anestesiol. 72, 151-169.

Cavaletti, G., Bogliun, G., Marzorati, L., Zincone, A., Piatti, M., Colombo, N., et al. (2004). Early predictors of peripheral neurotoxicity in cisplatin and paclitaxel combination chemotherapy. Ann. Oncol. 15, 1439-1442. doi: 10.1093/annonc/mdh348

Cavaletti, G., Gilardini, A., Canta, A., Rigamonti, L., Rodriguez-Menendez, V., Ceresa, C., et al. (2007). Bortezomib-induced peripheral neurotoxicity: a neurophysiological and pathological study in the rat. Exp. Neurol. 204, 317-325. doi: 10.1016/j.expneurol.2006.11.010

Cavaletti, G., and Marmiroli, P. (2010). Chemotherapy-induced peripheral neurotoxicity. Nat. Rev. Neurol. 6, 657-666. doi: 10.1038/nrneurol.2010.160

Cavaletti, G., Pezzoni, G., Pisano, C., Oggioni, N., Sala, F., Zoia, C., et al. (2002). Cisplatin-induced peripheral neurotoxicity in rats reduces the circulating levels of nerve growth factor. Neurosci. Lett. 322, 103-106. doi: 10.1016/S03043940(02)00091-5

Cavaletti, G., Tredici, G., Braga, M., and Tazzari, S. (1995). Experimental peripheral neuropathy induced in adult-rats by repeated intraperitoneal administration of taxol. Exp. Neurol. 133, 64-72. doi: 10.1006/exnr.1995.1008

Ceresa, C., and Cavaletti, G. (2011). Drug transporters in chemotherapy induced peripheral neurotoxicity: current knowledge and clinical implications. Curr. Med. Chem. 18, 329-341. doi: 10.2174/092986711794839160

Chen, H., and Chan, D. C. (2006). Critical dependence of neurons on mitochondrial dynamics. Curr. Opin. Cell Biol. 18, 453-459. doi: 10.1016/j.ceb.2006.06.004

Clapham, D. E. (2003). TRP channels as cellular sensors. Nature 426, 517-524. doi: 10.1038 /nature02196

Colombo, N., Bini, S., Miceli, D., Bogliun, G., Marzorati, L., Cavaletti, G., et al. (1995). Weekly cisplatin+/-glutathione in relapsed ovarian-carcinoma. Int. J. Gynecol. Cancer 5, 81-86. doi: 10.1046/j.1525-1438.1995.05020081.x

Costa, R., Motta, E. M., Dutra, R. C., Manjavachi, M. N., Bento, A. F., Malinsky, F. R., et al. (2011). Anti-nociceptive effect of kinin B-1 and B-2 receptor antagonists on peripheral neuropathy induced by paclitaxel in mice. Br. J. Pharmacol. 164, 681-693. doi: 10.1111/j.1476-5381.2011.01408.x

Croteau, D. L., Stierum, R. H., and Bohr, V. A. (1999). Mitochondrial DNA repair pathways. Mutat. Res. DNA Repair 434, 137-148. doi: 10.1016/S09218777(99)00025-7

Deng, L. T., Guindon, J., Vemuri, V. K., Thakur, G. A., White, F. A., Makriyannis, A., et al. (2012). The maintenance of cisplatin- and paclitaxel-induced mechanical and cold allodynia is suppressed by cannabinoid CB2 receptor activation and independent of CXCR4 signaling in models of chemotherapy-induced peripheral neuropathy. Mol. Pain 8, 1-12. doi: 10.1186/1744-8069-1188-1171

Descoeur, J., Pereira, V., Pizzoccaro, A., Francois, A., Ling, B., Maffre, V., et al. (2011). Oxaliplatin-induced cold hypersensitivity is due to remodelling of ion channel expression in nociceptors. Embo. Mol. Med. 3, 266-278. doi: 10.1002/emmm.201100134

Devigili, G., Tugnoli, V., Penza, P., Camozzi, F., Lombardi, R., Melli, G., et al. (2008). The diagnostic criteria for small fibre neuropathy: from symptoms to neuropathology. Brain 131, 1912-1925. doi: 10.1093/brain/awn093 
Di Cesare Mannelli, L., Zanardelli, M., Failli, P., and Ghelardini, C. (2012). Oxaliplatin-induced neuropathy: oxidative stress as pathological mechanism. protective effect of silibinin. J. Pain 13, 276-284. doi: 10.1016/j.jpain.2011.11.009

Di Marzo, V., Blumberg, P. M., and Szallasi, A. (2002). Endovanilloid signaling in pain. Curr. Opin. Neurobiol. 12, 372-379. doi: 10.1016/S0959-4388(02)00340-9

Dougherty, P. M., Cata, J. P., Cordella, J. V., Burton, A., and Weng, H.-R. (2004). Taxol-induced sensory disturbance is characterized by preferential impairment of myelinated fiber function in cancer patients. Pain 109, 132-142. doi: 10.1016/j.pain.2004.01.021

Doyle, T., Chen, Z., Muscoli, C., Bryant, L., Esposito, E., Cuzzocrea, S., et al. (2012). Targeting the overproduction of peroxynitrite for the prevention and reversal of paclitaxel-induced neuropathic pain. J. Neurosci. 32, 6149-6160. doi: 10.1523/JNEUROSCI.6343-11.2012

Farquhar-Smith, P. (2011). Chemotherapy-induced neuropathic pain. Curr. Opin. Support Palliat. Care 5, 1-7. doi: 10.1097/SPC.0b013e328342f9cc

Fidanboylu, M., Griffiths, L. A., and Flatters, S. J. L. (2011). Global inhibition of reactive oxygen species (ROS) inhibits paclitaxel-induced painful peripheral neuropathy. PLoS ONE 6:e25212. doi: 10.1371/journal.pone.0025212

Fischer, S. J., McDonald, E. S., Gross, L., and Windebank, A. J. (2001). Alterations in cell cycle regulation underlie cisplatin induced apoptosis of dorsal root ganglion neurons in vivo. Neurobiol. Dis. 8, 1027-1035. doi: 10.1006/nbdi.2001.0426

Flatters, S. J. L., and Bennett, G. J. (2004). Ethosuximide reverses paclitaxel- and vincristine-induced painful peripheral neuropathy. Pain 109, 150-161. doi: 10.1016/j.pain.2004.01.029

Flatters, S. J. L., and Bennett, G. J. (2006). Studies of peripheral sensory nerves in paclitaxel-induced painful peripheral neuropathy: evidence for mitochondrial dysfunction. Pain 122, 245-257. doi: 10.1016/j.pain.2006.01.037

Flatters, S. J. L., Xiao, W. H., and Bennett, G. J. (2006). Acetyl-L-carnitine prevents and reduces paclitaxel-induced painful peripheral neuropathy. Neurosci. Lett. 397, 219-223. doi: 10.1016/j.neulet.2005.12.013

Florea, A.-M., and Büsselberg, D. (2011). Cisplatin as an anti-tumor drug: cellular mechanisms of activity, drug resistance and induced side effects. Cancers 3, 1351-1371. doi: 10.3390/cancers3011351

Garcia, J. M., Cata, J. P., Dougherty, P. M., and Smith, R. G. (2008). Ghrelin prevents cisplatin-induced mechanical hyperalgesia and cachexia. Endocrinology 149, 455-460. doi: 10.1210/en.2007-0828

Gedlicka, C., Kornek, G. V., Schmid, K., and Scheithauer, W. (2003). Amelioration of docetaxel/cisplatin induced polyneuropathy by alpha-lipoic acid. Ann. Oncol. 14, 339-340. doi: 10.1093/annonc/mdg051

Gedlicka, C., Scheithauer, W., Schull, B., and Kornek, G. V. (2002). Effective treatment of oxaliplatin-induced cumulative polyneuropathy with alpha-lipoic acid. J. Clin. Oncol. 20, 3359-3361. doi: 10.1200/JCO.2002.99.502

Ghirardi, O., Vertechy, M., Vesci, L., Canta, A., Nicolini, G., Galbiati, S., et al. (2005). Chemotherapy-induced allodinia: neuroprotective effect of acetyl-Lcarnitine. In Vivo 19, 631-637.

Giannoccaro, M. P., Donadio, V., Gomis Perez, C., Borsini, W., Di Stasi, V., and Liguori, R. (2011). Somatic and autonomic small fiber neuropathy induced by bortezomib therapy: an immunofluorescence study. Neurol. Sci. 32, 361-363. doi: 10.1007/s10072-010-0475-2

Gilardini, A., Avila, R. L., Oggioni, N., Rodriguez-Menendez, V., Bossi, M., Canta, A., et al. (2012). Myelin structure is unaltered in chemotherapy-induced peripheral neuropathy. Neurotoxicology 33, 1-7. doi: 10.1016/j.neuro.2011.10.010

Gilchrist, L. (2012). Chemotherapy-induced peripheral neuropathy in pediatric cancer patients. Semin. Pediatr. Neurol. 19, 9-17. doi: 10.1016/j.spen.2012.02.011

Goel, S., Goldberg, G. L., Kuo, D. Y., Muggia, F., Arezzo, J., and Mani, S. (2008). Novel neurosensory testing in cancer patients treated with the epothilone B analog, ixabepilone. Ann. Oncol. 19, 2048-2052. doi: 10.1093/annonc/ $\operatorname{mdn} 420$

Goswami, C. (2012). TRPV1-tubulin complex: involvement of membrane tubulin in the regulation of chemotherapy-induced peripheral neuropathy. J. Neurochem. 123, 1-13. doi: 10.1111/j.1471-4159.2012.07892.x

Gregg, R. W., Molepo, J. M., Monpetit, V. J. A., Mikael, N. Z., Redmond, D., Gadia, M., et al. (1992). Cisplatin neurotoxicity-the relationship between dosage, time, and platinum concentration in neurologic tissues, and morphological evidence of toxicity. J. Clin. Oncol. 10, 795-803.

Grisold, W., Oberndorfer, S., and Windebank, A. J. (2012). Chemotherapy and Polyneuropathies. Eur. Assoc. NeuroOncol. Mag. 2, 25-36.
Gutiérrez-Gutiérrez, G., Sereno, M., Miralles, A., Casado-Sáenz, E., and GutiérrezRivas, E. (2010). Chemotherapy-induced peripheral neuropathy: clinical features, diagnosis, prevention and treatment strategies. Clin. Transl. Oncol. 12, 81-91. doi: 10.1007/S12094-010-0474-Z

Hansen, N., Uceyler, N., Palm, F., Zelenka, M., Biko, L., Lesch, K. P., et al. (2011). Serotonin transporter deficiency protects mice from mechanical allodynia and heat hyperalgesia in vincristine neuropathy. Neurosci. Lett. 495, 93-97. doi: 10.1016/j.neulet.2011.03.035

Herrmann, D. N., Griffin, J. W., Hauer, P., Cornblath, D. R., and McArthur, J. C. (1999). Epidermal nerve fiber density and sural nerve morphometry in peripheral neuropathies. Neurology 53, 1634-1640. doi: 10.1212/WNL.53.8.1634

Hershman, D. L., Fehrenbacher, L., Wade, R. J. L., Wong, S.-F., Hortobagyi, G. N., Meyskens, F. L., et al. (2013). Randomized double-blind placebo-controlled trial of acetyl-L-carnitine for the prevention of taxane-induced neuropathy in women undergoing adjuvant breast cancer therapy. J. Clin. Oncol. 31, 2627. doi: 10.1200/JCO.2012.44.8738

Hershman, D. L., Weimer, L. H., Wang, A., Kranwinkel, G., Brafman, L., Fuentes, D., et al. (2011). Association between patient reported outcomes and quantitative sensory tests for measuring long-term neurotoxicity in breast cancer survivors treated with adjuvant paclitaxel chemotherapy. Breast Cancer Res. Treat. 125, 767-774. doi: 10.1007/s10549-010-1278-0

Hilpert, F., Stahle, A., Tome, O., Burges, A., Rossner, D., Spathe, K., et al. (2005). Neuroprotection with amifostine in the first-line treatment of advanced ovarian cancer with carboplatin/paclitaxel-based chemotherapy-a double-blind, placebo-controlled, randomized phase II study from the Arbeitsgemeinschaft Gynakologische Onkologoie (AGO) Ovarian Cancer Study Group. Support. Care Cancer 13, 797-805. doi: 10.1007/s00520-005-0782-y

Holland, N. R., Crawford, T. O., Hauer, P., Cornblath, D. R., Griffin, J. W., and McArthur, J. C. (1998). Small-fiber sensory neuropathies: clinical course and neuropathology of idiopathic cases. Ann. Neurol. 44, 47-59. doi: 10.1002/ana.410440111

Hong, S. S., and Wiley, J. W. (2005). Early painful diabetic neuropathy is associated with differential changes in the expression and function of vanilloid receptor 1. J. Biol. Chem. 280, 618-627.

Hori, K., Ozaki, N., Suzuki, S., and Sugiura, Y. (2010). Upregulations of P2X(3) and ASIC3 involve in hyperalgesia induced by cisplatin administration in rats. Pain 149, 393-405. doi: 10.1016/j.pain.2010.03.005

Hoy, S. M. (2013). Subcutaneous bortezomib: in multiple myeloma. Drugs 73, 45-54. doi: 10.1007/s40265-013-0006-6

Ja'afer, F. M. H., Hamdan, F. B., and Mohammed, F. H. (2006). Vincristine-induced neuropathy in rat: electrophysiological and histological study. Exp. Brain Res. 173, 334-345.doi: 10.1007/s00221-006-0499-2

Jaggi, A. S., and Singh, N. (2012). Mechanisms in cancer-chemotherapeutic drugs-induced peripheral neuropathy. Toxicology 291, 1-9. doi: 10.1016/j.tox.2011.10.019

Jamieson, S. M. F., Liu, J. J., Connor, B., Dragunow, M., and McKeage, M. J. (2007). Nucleolar enlargement, nuclear eccentricity and altered cell body immunostaining characteristics of large-sized sensory neurons following treatment of rats with paclitaxel. Neurotoxicology 28, 1092-1098. doi: 10.1016/j.neuro.2007.04.009

Janes, K., Doyle, T., Bryant, L., Esposito, E., Cuzzocrea, S., Ryerse, J., et al. (2013). Bioenergetic deficits in peripheral nerve sensory axons during chemotherapy-induced neuropathic pain resulting from peroxynitritemediated post-translational nitration of mitochondrial superoxide dismutase. Pain 154, 2432-2440. doi: 10.1016/j.pain.2013.07.032

Ji, R. R., Samad, T. A., Jin, S. X., Schmoll, R., and Woolf, C. J. (2002). p38 MAPK activation by NGF in primary sensory neurons after inflammation increases TRPV1 levels and maintains heat hyperalgesia. Neuron 36, 57-68. doi: 10.1016/S0896-6273(02)00908-X

Jimenez-Andrade, J. M., Peters, C. M., Mejia, N. A., Ghilardi, J. R., Kuskowski, M. A., and Mantyh, P. W. (2006). Sensory neurons and their supporting cells located in the trigeminal, thoracic and lumbar ganglia differentially express markers of injury following intravenous administration of paclitaxel in the rat. Neurosci. Lett. 405, 62-67. doi: 10.1016/j.neulet.2006.06.043

Jin, H. W., Flatters, S. J. L., Xiao, W. H., Mulhem, H. L., and Bennett, G. J. (2008). Prevention of paclitaxel-evoked painful peripheral neuropathy by acetyl-L-carnitine: effects on axonal mitochondria, sensory nerve fiber terminal arbors, and cutaneous Langerhans cells. Exp. Neurol. 210, 229-237. doi: 10.1016/j.expneurol.2007.11.001 
Kagiava, A., Kosmidis, E. K., and Theophilidis, G. (2013). Oxaliplatin-induced hyperexcitation of rat sciatic nerve fibers: an intra-axonal study. Anticancer Agent. Med. Chem. 13, 373-379. doi: 10.2174/1871520611313020023

Kamei, J., Tamura, N., and Saitoh, A. (2005). Possible involvement of the spinal nitric oxide/cGMP pathway in vincristine-induced painful neuropathy in mice. Pain 117, 112-120. doi: 10.1016/j.pain.2005.05.026

Kamei, J., Zushida, K., Morita, K., Sasaki, M., and Tanaka, S. (2001). Role of vanilloid VR1 receptor in thermal allodynia and hyperalgesia in diabetic mice. Eur. J. Pharmacol. 422, 83-86. doi: 10.1016/S0014-2999(01)01059-7

Kanat, O., Evrensel, T., Baran, I., Coskun, H., Zarifoglu, M., Turan, O. F., et al. (2003). Protective effect of amifostine against toxicity of paclitaxel and carboplatin in non-small cell lung cancer: a single center randomized study. Med. Oncol. 20, 237-245. doi: 10.1385/MO:20:3:237

Kanavos, P. (2006). The rising burden of cancer in the developing world. Ann. Oncol. 17, 15-23. doi: 10.1093/annonc/mdl983

Kaur, G., Jaggi, A. S., and Singh, N. (2010). Exploring the potential effect of Ocimum sanctum in vincristine-induced neuropathic pain in rats. J. Brachial. Plex. Peripher. Nerve Inj. 5:3. doi: 10.1186/1749-7221-5-3

Kidd, J. F., Pilkington, M. F., Schell, M. J., Fogarty, K. E., Skepper, J. N., Taylor, C. W., et al. (2002). Paclitaxel affects cytosolic calcium signals by opening the mitochondrial permeability transition pore. J. Biol. Chem. 277, 6504-6510. doi: 10.1074/jbc.M106802200

Kim, H. K., Zhang, Y. P., Gwak, Y. S., and Abdi, S. (2010). Phenyl Ntert-butylnitrone, a free radical scavenger, reduces mechanical allodynia in chemotherapy-induced neuropathic pain in rats. Anesthesiology 112, 432-439. doi: 10.1097/ALN.0b013e3181ca31bd

Kishi, M., Tanabe, J., Schmelzer, J. D., and Low, P. A. (2002). Morphometry of dorsal root ganglion in chronic experimental diabetic neuropathy. Diabetes 51, 819-824. doi: 10.2337/diabetes.51.3.819

Kocer, B., Sucak, G., Kuruoglu, R., Aki, Z., Haznedar, R., and Erdogmus, N. I. (2009). Clinical and electrophysiological evaluation of patients with thalidomide-induced neuropathy. Acta Neurol. Belg. 109, 120-126.

Kurniali, P. C., Luo, L. G., and Weitberg, A. B. (2010). Role of calcium/magnesium infusion in oxaliplatin-based chemotherapy for colorectal cancer patients. Oncology 24, 289-292.

Landowski, T. H., Megli, C. J., Nullmeyer, K. D., Lynch, R. M., and Dorr, R. T. (2005). Mitochondrial-mediated disregulation of $\mathrm{Ca} 2+$ is a critical determinant of Velcade (PS-341/Bortezomib) cytotoxicity in myeloma cell lines. Cancer Res. 65, 3828-3836. doi: 10.1158/0008-5472.CAN-04-3684

Lauria, G., Morbin, M., Lombardi, R., Borgna, M., Mazzoleni, G., Sghirlanzoni, A., et al. (2003). Axonal swellings predict the degeneration of epidermal nerve fibers in painful neuropathies. Neurology 61, 631-636. doi: 10.1212/01.WNL.0000070781.92512.A4

Lee, J., Giordano, S., and Zhang, J. (2012). Autophagy, mitochondria and oxidative stress: cross-talk and redox signalling. Biochem. J. 441, 523-540. doi: 10.1042/BJ20111451

Lin, P. C., Lee, M. Y., Wang, W. S., Yen, C. C., Chao, T. C., Hsiao, L. T., et al. (2006). $\mathrm{N}$-acetylcysteine has neuroprotective effects against oxaliplatin-based adjuvant chemotherapy in colon cancer patients: preliminary data. Support. Care Cancer 14, 484-487. doi: 10.1007/s00520-006-0018-9

Ling, B., Coudoré-Civiale, M., Balayssac, D., Eschalier, A., Coudoré, F., and Authier, N. (2007). Behavioral and immunohistological assessment of painful neuropathy induced by a single oxaliplatin injection in the rat. Toxicology 234, 176-184. doi: 10.1016/j.tox.2007.02.013

Liu, C. C., Lu, N., Cui, Y., Yang, T., Zhao, Z. Q., Xin, W. J., et al. (2010). Prevention of paclitaxel-induced allodynia by minocycline: effect on loss of peripheral nerve fibers and infiltration of macrophages in rats. Mol. Pain 6:76. doi: 10.1186/17448069-6-76

Lomonaco, M., Milone, M., Batocchi, A. P., Padua, L., Restuccia, D., and Tonali, P. (1992). Cisplatin neuropathy: clinical course and neurophysiological findings. J. Neurol. 239, 199-204. doi: 10.1007/BF00839140

Lorusso, D., Ferrandina, G., Greggi, S., Gadducci, A., Pignata, S., Tateo, S., et al. (2003). Phase III multicenter randomized trial of amifostine as cytoprotectant in first-line chemotherapy in ovarian cancer patients. Ann. Oncol. 14, 1086-1093. doi: 10.1093/annonc/mdg301

Løseth, S., Stålberg, E., Jorde, R., Mellgren, S. I., Institutionen För, N., Uppsala, U., et al. (2008). Early diabetic neuropathy: thermal thresholds and intraepidermal nerve fibre density in patients with normal nerve conduction studies. J. Neurol. 255, 1197-1202. doi: 10.1007/s00415-008-0872-0
Lu, P., Fan, Q. X., Wang, L. X., Wang, X., Zong, H., and Wang, R. L. (2008). Prophylactic effect of amifostine on oxaliplatin-related neurotoxicity in patients with digestive tract tumors. Ai Zheng 27, 1117-1120.

Luo, Z. D., Chaplan, S. R., Higuera, E. S., Sorkin, L. S., Stauderman, K. A., Williams, M. E., et al. (2001). Upregulation of dorsal root ganglion alpha(2)delta calcium channel subunit and its correlation with allodynia in spinal nerve-injured rats. J. Neurosci. 21, 1868-1875.

Maestri, A., Ceratti, A. D. P., Cundari, S., Zanna, C., Cortesi, E., and Crino, L. (2005). A pilot study on the effect of acetyl-L-carnitine in paclitaxel-and cisplatin-induced peripheral neuropathy. Tumori 91, 135-138.

McDonald, E. S., Randon, K. R., Knight, A., and Windebank, A. J. (2005). Cisplatin preferentially binds to DNA in dorsal root ganglion neurons in vitro and in vivo: a potential mechanism for neurotoxicity. Neurobiol. Dis. 18, 305-313. doi: 10.1016/j.nbd.2004.09.013

Melli, G., Taiana, M., Camozzi, F., Triolo, D., Podini, P., Quattrini, A., et al. (2008). Alpha-lipoic acid prevents mitochondrial damage and neurotoxicity in experimental chemotherapy neuropathy. Exp. Neurol. 214, 276-284. doi: 10.1016/j.expneurol.2008.08.013

Meregalli, C., Canta, A., Carozzi, V. A., Chiorazzi, A., Oggioni, N., Gilardini, A., et al. (2010). Bortezomib-induced painful neuropathy in rats: a behavioral, neurophysiological and pathological study in rats. Eur. J. Pain 14, 343-350. doi: 10.1016/j.ejpain.2009.07.001

Meyer, L., Patte-Mensah, C., Taleb, O., and Mensah-Nyagan, A.G. (2011). Allopregnanolone prevents and suppresses oxaliplatin-evoked painful neuropathy: multi-parametric assessment and direct evidence. Pain 152, 170-181. doi: 10.1016/j.pain.2010.10.015

Mihara, Y., Egashira, N., Sada, H., Kawashiri, T., Ushio, S., Yano, T., et al. (2011). Involvement of spinal NR2B-containing NMDA receptors in oxaliplatininduced mechanical allodynia in rats. Mol. Pain 7, 1-7. doi: 10.1186/17448069-7-8

Milla, P., Airoldi, M., Weber, G., Drescher, A., Jaehde, U., and Cattel, L. (2009). Administration of reduced glutathione in FOLFOX4 adjuvant treatment for colorectal cancer: effect on oxaliplatin pharmacokinetics, Pt-DNA adduct formation, and neurotoxicity. Anti-Cancer Drugs 20, 396-402. doi: 10.1097/CAD.0b013e32832a2dc1

Mimura, Y., Kato, H., Eguchi, K., and Ogawa, T. (2000). Schedule dependency of paclitaxel-induced neuropathy in mice: a morphological study. Neurotoxicology 21, 513-520.

Mir, O., Alexandre, J., Tran, A., Durand, J. P., Pons, G., Treluyer, J. M., et al. (2009). Relationship between GSTP1 Ile105Val polymorphism and docetaxel-induced peripheral neuropathy: clinical evidence of a role of oxidative stress in taxane toxicity. Ann. Oncol. 20, 736-740. doi: 10.1093/annonc/ mdn698

Mironov, S. L. (2007). ADP regulates movements of mitochondria in neurons. Biophysical J. 92, 2944-2952. doi: 10.1529/biophysj.106.092981

Mo, M., Erdelyi, I., Szigeti-Buck, K., Benbow, J. H., and Ehrlich, B. E. (2012). Prevention of paclitaxel-induced peripheral neuropathy by lithium pretreatment. FASEB J. 26, 4696-4709. doi: 10.1096/fj.12-214643

Moore, D. H., Donnelly, J., McGuire, W. P., Almadrones, L., Cella, D. F., Herzog, T. J., et al. (2003). Limited access trial using amifostine for protection against cisplatin- and three-hour paclitaxel-induced neurotoxicity: a phase II study of the Gynecologic Oncology Group. J. Clinical Oncol. 21, 4207-4213. doi: 10.1200/JCO.2003.02.086

Muthuraman, A., Jaggi, A. S., Singh, N., and Singh, D. (2008). Ameliorative effects of amiloride and pralidoxime in chronic constriction injury and vincristine induced painful neuropathy in rats. Eur. J. Pharmacol. 587, 104-111. doi: 10.1016/j.ejphar.2008.03.042

Nahman-Averbuch, H., Yarnitsky, D., Granovsky, Y., Sprecher, E., Steiner, M., TzukShina, T., et al. (2011). Pronociceptive pain modulation in patients with painful chemotherapy-induced polyneuropathy. J. Pain Symptom Manage. 42, 229-238. doi: 10.1016/j.jpainsymman.2010.10.268

Nakashima, T., Kiba, T., Ogawa, Y., Hosokawa, A., Shintani, H., Okada, Y., et al. (2012). A case of paclitaxel-induced peripheral neuropathy successfully treated with pregabalin. Gan To Kagaku Ryoho 39, 1443-1445.

Nasu, S., Misawa, S., Nakaseko, C., Shibuya, K., Isose, S., Sekiguchi, Y., et al. (2013). Bortezomib-induced neuropathy: axonal membrane depolarization precedes development of neuropathy. Clin. Neurophysiol. doi: 10.1016/j.clinph.2013. 07.014. [Epub ahead of print]. 
Nguyen, V. H., and Lawrence, H. J. (2004). Use of gabapentin in the prevention of taxane-induced arthralgias and myalgias. J. Clin. Oncol. 22, 1767-1769. doi: 10.1200/JCO.2004.99.298

Nieto, F. R., Cendan, C. M., Sanchez-Fernandez, C., Jose Cobos, E., Entrena, J. M., Tejada, M. A., et al. (2012). Role of sigma-1 receptors in paclitaxelinduced neuropathic pain in mice. J. Pain 13, 1107-1121. doi: 10.1016/j.jpain. 2012.08.006

Norcini, M., Vivoli, E., Galeotti, N., Bianchi, E., Bartolini, A., and Ghelardini, C. (2009). Supraspinal role of protein kinase C in oxaliplatin-induced neuropathy in rat. Pain 146, 141-147. doi: 10.1016/j.pain.2009.07.017

Ocean, A. J., and Vahdat, L. T. (2004). Chemotherapy-induced peripheral neuropathy: pathogenesis and emerging therapies. Support. Care Cancer 12, 619-625. doi: 10.1007/s00520-004-0657-7

Orlando, G., Pietro Lo, G., Claudio, P., Mario, V., Augusta, B., Loredana, V., et al. (2005). Acetyl-L-carnitine prevents and reverts experimental chronic neurotoxicity induced by oxaliplatin, without altering its antitumor properties. Anticancer Res. 25, 2681-2687.

Pabbidi, R. M., Yu, S. Q., Peng, S., Khardori, R., Pauza, M. E., and Premkumar, L. S. (2008). Influence of TRPV1 on diabetes-induced alterations in thermal pain sensitivity. Mol. Pain 4:9. doi: 10.1186/1744-8069-4-9

Pachman, D. R., Barton, D. L., Watson, J. C., and Loprinzi, C. L. (2011). Chemotherapy-induced peripheral neuropathy: prevention and treatment. Clin. Pharmacol. Ther. 90, 377-387. doi: 10.1038/clpt.2011.115

Paice, J. A. (2011). Chronic treatment-related pain in cancer survivors. Pain 152, S84-S89. doi: 10.1016/j.pain.2010.10.010

Park, S. B., Lin, C. S. Y., Krishnan, A. V., Goldstein, D., Friedlander, M. L., and Kiernan, M. C. (2011). Utilizing natural activity to dissect the pathophysiology of acute oxaliplatin-induced neuropathy. Exp. Neurol. 227, 120-127. doi: 10.1016/j.expneurol.2010.10.002

Pascual, D., Goicoechea, C., Burgos, E., and Martin, M. I. (2010). Antinociceptive effect of three common analgesic drugs on peripheral neuropathy induced by paclitaxel in rats. Pharmacol. Biochem. Behav. 95, 331-337. doi: 10.1016/j.pbb.2010.02.009

Pastorino, J. G., Snyder, J. W., Serroni, A., Hoek, J. B., and Farber, J.L. (1993). Cyclosporine and carnitine prevent the anoxic death of cultured-hepatocytes by inhibiting the mitochondrial permeability transition. J. Biol. Chem. 268 13791-13798.

Peltier, A. C., and Russell, J. W. (2002). Recent advances in drug-induced neuropathies. Curr. Opin. Neurol. 15, 633-638. doi: 10.1097/00019052-20021000000015

Peng, P., Xi, Q. S., Xia, S., Zhuang, L., Gui, Q., Chen, Y., et al. (2012). Pregabalin attenuates docetaxel-induced neuropathy in rats. J. Huazhong Uni. Sci. Technolog. Med. Sci. 32, 586-590. doi: 10.1007/s11596-012-1001-y

Periquet, M. I., Mendell, J. R., Novak, V., Collins, M. P., Nagaraja, H. N., Erdem, S., et al. (1999). Painful sensory neuropathy_prospective evaluation using skin biopsy. Neurology 53, 1641-1647. doi: 10.1212/WNL.53.8.1641

Persohn, E., Canta, A., Schoepfer, S., Traebert, M., Mueller, L., Gilardini, A., et al. (2005). Morphological and morphometric analysis of paclitaxel and docetaxelinduced peripheral neuropathy in rats. Eur. J. Cancer 41, 1460-1466. doi: 10.1016/j.ejca.2005.04.006

Peters, C. M., Jimenez-Andrade, J. M., Kuskowski, M. A., Ghilardi, J. R., and Mantyh, P. W. (2007). An evolving cellular pathology occurs in dorsal root ganglia, peripheral nerve and spinal cord following intravenous administration of paclitaxel in the rat. Brain Res. 1168, 46-59. doi: 10.1016/j.brainres.2007. 06.066

Podratz, J. L., Knight, A. M., Ta, L. E., Staff, N. P., Gass, J. M., Genelin, K., et al. (2011). Cisplatin induced Mitochondrial DNA damage in dorsal root ganglion neurons. Neurobiol. Dis. 41, 661-668. doi: 10.1016/j.nbd.2010.11.017

Polomano, R. C., Mannes, A. J., Clark, U. S., and Bennett, G. J. (2001). A painful peripheral neuropathy in the rat produced by the chemotherapeutic drug, paclitaxel. Pain 94, 293-304. doi: 10.1016/S0304-3959(01)00363-3

Postma, T. J., Vermorken, J. B., Liefting, A. J. M., Pinedo, H. M., and Heimans, J. J. (1995). Paclitaxel-induced neuropathy. Ann. Oncol. 6, 489-494.

Quasthoff, S., and Hartung, H. P. (2002). Chemotherapy-induced peripheral neuropathy. J. Neurol. 249, 9-17. doi: 10.1007/PL00007853

Ribeiro-Da-Silva, A., Kenigsberg, R. L., and Cuello, A. C. (1991). Light and electron microscopic distribution of nerve growth factor receptor-like immunoreactivity in the skin of the rat lower lip. Neuroscience 43, 631-646. doi: 10.1016/03064522(91)90322-F
Richardson, P. G., Xie, W., Mitsiades, C., Chanan-Khan, A. A., Lonial, S., Hassoun, H., et al. (2009). Single-agent bortezomib in previously untreated multiple myeloma: efficacy, characterization of peripheral neuropathy, and molecular correlations with response and neuropathy. J. Clinical Oncol. 27, 3518-3525. doi: 10.1200/JCO.2008.18.3087

Roberts, J. A., Jenison, E. L., Kim, K., Clarke-Pearson, D., and Langleben, A. (1997). A Randomized, multicenter, double-blind, placebo-controlled, dosefinding study of ORG 2766 in the prevention or delay of cisplatin-induced neuropathies in women with ovarian cancer. Gynecol. Oncol. 67, 172-177. doi: 10.1006/gyno.1997.4832

Roglio, I., Bianchi, R., Camozzi, F., Carozzi, V., Cervellini, I., Crippa, D., et al. (2009). Docetaxel-induced peripheral neuropathy: protective effects of dihydroprogesterone and progesterone in an experimental model. JPNS 14, 36-44. doi: 10.1111/j.1529-8027.2009.00204.x

Saha, L., Hota, D., and Chakrabarti, A. (2012). Evaluation of lercanidipine in Paclitaxel-induced neuropathic pain model in rat: a preliminary study. Pain res. Treat. 2012:143579. doi: 10.1155/2012/143579

Sahenk, Z., Barohn, R., New, P., and Mendell, J. R. (1994). Taxol neuropathy. Electrodiagnostic and sural nerve biopsy findings. Arch. Neurol. 51, 726-729. doi: 10.1001/archneur.1994.00540190110024

Saif, M. W., Syrigos, K., Kaley, K., and Isufi, I. (2010). Role of pregabalin in treatment of oxaliplatin-induced sensory neuropathy. Anticancer Res. 30, 2927-2933.

Schlegel, U. (2011). Central nervous system toxicity of chemotherapy. Eur. Assoc. NeuroOncol. Mag. 1, 25-29.

Schmeichel, A. M., Schmelzer, J. D., and Low, P. A. (2003). Oxidative injury and apoptosis of dorsal root ganglion neurons in chronic experimental diabetic neuropathy. Diabetes 52, 165-171. doi: 10.2337/diabetes.52.1.165

Schmidt, R. E., Dorsey, D., Parvin, C. A., Beaudet, L. N., Plurad, S. B., and Roth, K. A. (1997). Dystrophic axonal swellings develop as a function of age and diabetes in human dorsal root ganglia. J. Neuropathol. Exp. Neurol. 56, 1028-1043. doi: 10.1097/00005072-199709000-00008

Screnci, D., and McKeage, M. J. (1999). Platinum neurotoxicity: clinical profiles, experimental models and neuroprotective approaches. J. Inorg. Biochem. 77, 105-110. doi: 10.1016/S0162-0134(99)00135-X

Scuteri, A., Galimberti, A., Maggioni, D., Ravasi, M., Pasini, S., Nicolini, G., et al. (2009). Role of MAPKs in platinum-induced neuronal apoptosis. Neurotoxicology 30, 312-319. doi: 10.1016/j.neuro.2009.01.003

Scuteri, A., Galimberti, A., Ravasi, M., Pasini, S., Donzelli, E., Cavaletti, G., et al. (2010). NGF protects dorsal root ganglion neurons from oxaliplatin by modulating JNK/Sapk and ERK1/2. Neurosci. Lett. 486, 141-145. doi: 10.1016/j.neulet.2010.09.028

Siau, C., and Bennett, G. J. (2006). Dysregulation of cellular calcium homeostasis in chemotherapy-evoked painful peripheral neuropathy. Anesth. Analg. 102, 1485-1490. doi: 10.1213/01.ane.0000204318.35194.ed

Smith, E. M. L., Pang, H., Cirrincione, C., Fleishman, S., Paskett, E. D., Ahles, T., et al. (2013). Effect of duloxetine on pain, function, and quality of life among patients with chemotherapy-induced painful peripheral neuropathy: a randomized clinical trial. JAMA 309, 1359-1367. doi: 10.1001/jama. 2013.2813

Smyth, J. F., Bowman, A., Perren, T., Wilkinson, P., Prescott, R. J., Quinn, K. J., et al. (1997). Glutathione reduces the toxicity and improves quality of life of women diagnosed with ovarian cancer treated with cisplatin: results of a double-blind, randomised trial. Ann. Oncol. 8, 569-573. doi: 10.1023/A:1008211226339

Sorensen, L., Molyneaux, L., and Yue, D. K. (2006). The relationship among pain, sensory loss, and small nerve fibers in diabetes. Diabetes Care 29, 883-887. doi: 10.2337/diacare.29.04.06.dc05-2180

Stucky, C. L., and Lewin, G. R. (1999). Isolectin B4-positive and -negative nociceptors are functionally distinct. J. Neurosci. 19, 6497-6505.

Suzukawa, K., Miura, K., Mitsushita, J., Resau, J., Hirose, K., Crystal, R., et al. (2000). Nerve growth factor-induced neuronal differentiation requires generation of Rac1-regulated reactive oxygen species. J. Biol. Chem. 275, 13175-13178. doi: 10.1074/jbc.275.18.13175

Ta, L. E., Bieber, A. J., Carlton, S. M., Loprinzi, C. L., Low, P. A., and Windebank, A. J. (2010). Transient Receptor Potential Vanilloid 1 is essential for cisplatininduced heat hyperalgesia in mice. Mol. Pain 6:15. doi: 10.1186/1744-8069-6-15

Ta, L. E., Espeset, L., Podratz, J., and Windebank, A. J. (2006). Neurotoxicity of oxaliplatin and cisplatin for dorsal root ganglion neurons correlates with platinum-DNA binding. Neurotoxicology 27, 992-1002. doi: 10.1016/j.neuro. 2006.04.010 
Ta, L. E., Schmelzer, J. D., Bieber, A. J., Loprinzi, C. L., Sieck, G. C., Brederson, J. D., et al. (2013). A novel and selective poly (ADP-ribose) polymerase inhibitor ameliorates chemotherapy-induced painful neuropathy. PLOS ONE 8:e54261. doi: 10.1371/journal.pone.0054161

Tanner, K. D., Levine, J. D., and Topp, K. S. (1998). Microtubule disorientation and axonal swelling in unmyelinated sensory axons during vincristineinduced painful neuropathy in rat. J. Comp. Neurol. 395, 481-492. doi: 10.1002/(SICI)1096-9861(19980615)395:4<481::AID-CNE5>3.3.CO;2-T

Tatsushima, Y., Egashira, N., Kawashiri, T., Mihara, Y., Yano, T., Mishima, K., et al. (2011). Involvement of substance P in peripheral neuropathy induced by paclitaxel but not oxaliplatin. J. Pharmacol. Exp. Ther. 337, 226-235. doi: 10.1124/jpet.110.175976

Tatsushima, Y., Egashira, N., Narishige, Y., Fukui, S., Kawashiri, T., Yamauchi, Y., et al. (2013). Calcium channel blockers reduce oxaliplatin-induced acute neuropathy: a retrospective study of 69 male patients receiving modified FOLFOX6 therapy. Biomed. Pharmacother. 67, 39-42. doi: 10.1016/j.biopha. 2012.10.006

Topp, K. S., Tanner, K. D., and Levine, J. D. (2000). Damage to the cytoskeleton of large diameter sensory neurons and myelinated axons in vincristine-induced painful peripheral neuropathy in the rat. J. Comp. Neurol. 424, 563-576. doi: 10.1002/1096-9861(20000904)424:4<563::AID-CNE1>3.3.CO;2-L

Trevisan, G., Materazzi, S., Fusi, C., Altomare, A., Aldini, G., Lodovici, M., et al. (2013). Novel therapeutic strategy to prevent chemotherapy-induced persistent sensory neuropathy by TRPA1 blockade. Cancer Res.73, 3120. doi: 10.1158/0008-5472.CAN-12-4370

Tsujino, H., Kondo, E., Fukuoka, T., Dai, Y., Tokunaga, A., Miki, K., et al. (2000). Activating transcription factor 3 (ATF3) induction by axotomy in sensory and motoneurons: a novel neuronal marker of nerve injury. Mol. Cell Neurosci. 15, 170-182. doi: 10.1006/mcne.1999.0814

van, D. H. R. G., Vecht, C. J., van, D. B. M. E., Elderson, A., Boogerd, W., Heimans, J. J., et al. (1990). Prevention of cisplatin neurotoxicity with an ACTH(4-9) analogue in patients with ovarian cancer. N. Engl. J. Med. 322, 89-94. doi: 10.1056/NEJM199001113220204

Velasco, R., and Bruna, J. (2010). Chemotherapy-induced peripheral neuropathy: an unresolved issue. Neurologia 25, 116-131. doi: 10.1016/S02134853(10)70036-0

Wang, H.-T., Liu, Z.-G., Yang, W., Liao, A.-J., Zhang, R., Wu, B., et al. (2011). Study on mechanism of bortezomib inducing peripheral neuropathy and the reversing effect of reduced glutathione. Zhonghua xue ye xue za zhi 32, 107-111.

Wang, X.-M., Lehky, T. J., Brell, J. M., and Dorsey, S. G. (2012). Discovering cytokines as targets for chemotherapy-induced painful peripheral neuropathy. Cytokine 59, 3-9. doi: 10.1016/j.cyto.2012.03.027

Warwick, R. A., and Hanani, M. (2013). The contribution of satellite glial cells to chemotherapy-induced neuropathic pain. Eur. J. Pain 17, 571-580. doi: 10.1002/j.1532-2149.2012.00219.x

Wen, F., Zhou, Y., Wang, W., Hu, Q. C., Liu, Y. T., Zhang, P. F., et al. (2013). $\mathrm{Ca} / \mathrm{Mg}$ infusions for the prevention of oxaliplatin-related neurotoxicity in patients with colorectal cancer: a meta-analysis. Ann. Oncol. 24, 171-178. doi: 10.1093/annonc/mds211

Wilkes, G. (2007). Peripheral neuropathy related to chemotherapy. Semin. Oncol. Nurs. 23, 162-173. doi: 10.1016/j.soncn.2007.05.001

Windebank, A. J., and Grisold, W. (2008). Chemotherapy-induced neuropathy. J. Peripheral Nervous Sys. 13, 27-46. doi: 10.1111/j.1529-8027.2008.00156.x
Wolf, S., Barton, D., Kottschade, L., Grothey, A., and Loprinzi, C. (2008). Chemotherapy-induced peripheral neuropathy: prevention and treatment strategies. Eur. J. Cancer 44, 1507-1515. doi: 10.1016/j.ejca.2008.04.018

Woodbury, C. J., Zwick, M., Wang, S. Y., Lawson, J. J., Caterina, M. J., Koltzenburg, M., et al. (2004). Nociceptors lacking TRPV1 and TRPV2 have normal heat responses. J. Neurosci. 24, 6410-6415. doi: 10.1523/JNEUROSCI.1421-04.2004

Xiao, W., Boroujerdi, A., Bennett, G. J., and Luo, Z. D. (2007). Chemotherapyevoked painful peripheral neuropathy: analgesic effects of gabapentin and effects on expression of the alpha-2-delta type-1 calcium channel subunit. Neuroscience 144, 714-720. doi: 10.1016/j.neuroscience.2006.09.044

Xiao, W. H., and Bennett, G. J. (2012). Effects of mitochondrial poisons on the neuropathic pain produced by the chemotherapeutic agents, paclitaxel and oxaliplatin. Pain 153, 704-709. doi: 10.1016/j.pain.2011.12.011

Xiao, W. H., Zheng, F. Y., Bennett, G. J., Bordet, T., and Pruss, R. M. (2009). Olesoxime (cholest-4-en-3-one, oxime): analgesic and neuroprotective effects in a rat model of painful peripheral neuropathy produced by the chemotherapeutic agent, paclitaxel. Pain 147, 202-209. doi: 10.1016/j.pain.2009.09.006

Xiao, W. H., Zheng, H., and Bennett, G. J. (2012). Characterization of oxaliplatininduced chronic painful peripheral neuropathy in the rat and comparison with the neuropathy induced by paclitaxel. Neuroscience 203, 194-206. doi: 10.1016/j.neuroscience.2011.12.023

Xiao, W. H., Zheng, H., Zheng, F. Y., Nuydens, R., Meert, T. F., and Bennett, G. J. (2011). Mitochondrial abnormality in sensory, but not motor, axons in paclitaxel-evoked painful peripheral neuropathy in the rat. Neuroscience 199, 461-469. doi: 10.1016/j.neuroscience.2011.10.010

Yoon, S. Y., Robinson, C. R., Zhang, H., and Dougherty, P. M. (2013). Spinal astrocyte gap junctions contribute to oxaliplatin-induced mechanical hypersensitivity. J. Pain 14, 205-214. doi: 10.1016/j.jpain.2012.11.002

Zheng, H., Xiao, W. H., and Bennett, G. J. (2011). Functional deficits in peripheral nerve mitochondria in rats with paclitaxel- and oxaliplatinevoked painful peripheral neuropathy. Exp. Neurol. 232, 154-161. doi: 10.1016/j.expneurol.2011.08.016

Zheng, H., Xiao, W. H., and Bennett, G. J. (2012). Mitotoxicity and bortezomibinduced chronic painful peripheral neuropathy. Exp. Neur. 238, 225-234. doi: 10.1016/j.expneurol.2012.08.023

Conflict of Interest Statement: The authors declare that the research was conducted in the absence of any commercial or financial relationships that could be construed as a potential conflict of interest.

Received: 03 October 2013; accepted: 28 November 2013; published online: 18 December 2013.

Citation: Han Y and Smith MT (2013) Pathobiology of cancer chemotherapyinduced peripheral neuropathy (CIPN). Front. Pharmacol. 4:156. doi: 10.3389/fphar. 2013.00156

This article was submitted to Neuropharmacology, a section of the journal Frontiers in Pharmacology.

Copyright (c) 2013 Han and Smith. This is an open-access article distributed under the terms of the Creative Commons Attribution License (CC BY). The use, distribution or reproduction in other forums is permitted, provided the original author(s) or licensor are credited and that the original publication in this journal is cited, in accordance with accepted academic practice. No use, distribution or reproduction is permitted which does not comply with these terms. 